\title{
New osteichthyans (bony fishes) from the Devonian of Central Australia
}

\author{
Gavin C. Young ${ }^{*}, 1$ \& Hans-Peter Schultze ${ }^{2}$ \\ ${ }^{1}$ Department of Earth \& Marine Sciences, Australian National University, Canberra 0200, Australia \\ 2 Museum für Naturkunde der Humboldt-Universität zu Berlin, Invalidenstr. 43, D-10115 Berlin, Germany \\ Private: 2001 Vermont St., Lawrence, Kansas 66046, USA
}

Received 30 October 2004, accepted 3 May 2005

Published online 02.11.2005

With 10 figures and 2 tables

Key words: Osteichthyans, dipnoans, osteolepidids, onychodontids, Devonian, central Australia.

\begin{abstract}
Osteichthyan remains described from two localities in Central Australia (Mount Winter, Amadeus Basin, and southern Toomba Range, Georgina Basin) include the dipnoan Amadeodipterus kencampbelli n. gen., n. sp., the osteolepidid Muranjilepis winterensis n. gen., n. sp., and the onychodontid Luckeus abudda n. gen., n. sp., as well as indeterminate holoptychiid scales, osteolepidid scales of a new type from the Georgina Basin locality, and indeterminate onychodontid remains from both localities. Amadeodipterus n. gen. is a short-headed dipterid dipnoan with bones A and $\mathrm{H}$ enclosed into the skull roof; Muranjilepis n. gen. is a small form with short postparietal and parietoethmoidal shields, large orbits, and large pores of the sensory line system. It is closest to Thursius, and some Chinese osteolepidid material. Luckeus n. gen. is based on an onychodontid lower jaw with Meckel's cartilage separately ossified perichondrally from the dentary and infradentary, and carrying the parasymphysial tooth whorl. Different osteichthyan taxa at the two localities indicate a difference in age and/or palaeoenvironment within the Early-Middle Devonian.
\end{abstract}

Schlïsselwörter: Knochenfische, Dipnoi, osteolepidide und onychodontide Sarcopterygier, Devon, Zentralaustralien.

\section{Zusammenfassung}

Knochenfischreste aus zwei Fundorten Zentralaustraliens (Mount Winter, Amadeus Becken und südlicher Toomba Rücken, Georgina Becken) umfassen den Lungenfisch Amadeodipterus kencampbelli n. gen., n. sp., den osteolepididen Sarcopterygier Muranjilepis winterensis n. gen., n. sp., und den onychodontiden Sarcopterygier Luckeus abudda n. gen., n. sp., sowie unbestimmte holoptychiide und osteolepidide Schuppen eines neuen Typs aus dem Fundort im Georgina Becken und unbestimmte onychodontide Reste von beiden Fundorten. Amadeodipterus n. gen. ist ein kurz-schädeliger Lungenfisch, bei dem die Knochen $\mathrm{A}$ und $\mathrm{H}$ in das Schädeldach miteingeschlossen sind. Bei Muranjilepis $\mathrm{n}$. gen. handelt es sich um einen kleinen Osteolepididen mit kurzem Postparietal- und Parietoethmoidal-Schild, großen Augenhöhlen und großen Poren des Sinneskanalsystems; er ist am nächsten mit Thursius und einigen chinesischen Osteolepididen verwandt. Ein unbestimmter onychodontider Unterkiefer zeigt ein wahrscheinlich primitives Merkmal in der perichondralen Verknöcherung des Meckelschen Knorpels getrennt von Dentale und Infradentale, der die Unterlage der parasymphysialen Zahnspirale bildet. Verschiedene Knochenfischtaxa treten an den beiden Lokalitäten auf; das deutet auf unterschiedliches Alter und/oder Palaeoenviroment an der Unter-Mitteldevongrenze zwischen beiden Lokalitäten hin.

\section{Introduction}

The osteichthyans (true bony fishes) from the Devonian of Australia are still poorly known, with some exceptions. The Dipnoi (lungfishes) are the best documented group, first reported from the Lower Devonian of Burrinjuck in southeastern Australia (Etheridge 1906; Camp-

\footnotetext{
* Corresponding author, e-mail: gavinyoung@homemail.com.au
} 
bell et al. 2000). Hills (1929) identified lungfish toothplates in the Middle-Upper Devonian sequence of Victoria, Long (1987a, 1992) documented much more complete remains from this sequence, and Ahlberg et al. (2001) compared the Late Devonian lungfish Soederberghia from New South Wales with the same genus in North America and Greenland. Miles (1977) first monographed the exceptionally preserved lungfish material from the Upper Devonian (Frasnian) Gogo deposit in Western Australia (Campbell \& Barwick 1999 summarised extensive subsequent work on Gogo dipnoans). Other major osteichthyan groups are documented from the same regions: Actinopterygii (ray-finned fishes) from the Lower Devonian of Burrinjuck (Schultze 1968; Basden et al. 2000a; Basden \& Young 2001), the Middle-Upper Devonian of Victoria (Long 1988), and the Gogo fauna (Gardiner 1984), and various sarcopterygians from southeastern Australia (Thomson 1973; Young \& Gorter 1981; Long 1985, 1987b; Johanson \&
Ahlberg 1997, 1998; Ahlberg \& Johanson 1997). The first Australian Devonian coelacanth comes from Victoria (Long 1999), and the exceptionally preserved osteolepidid Gogonasus and onychodontid Onychodus from the Gogo fauna provide a wealth of new morphological data (Long et al. 1997; Andrews et al., in press). Fragmentary Early Devonian onychodont remains are known from Burrinjuck (Ørvig 1969; Lindley 2002), and otherwise the widespread occurrence of osteichthyans is indicated by a significant component in various microvertebrate assemblages (e.g. Basden et al. 2000b; Burrow 1994, 1995a, b, 1997; Turner et al. 2000).

All of the localities mentioned so far lie either in the sedimentary basins of the western continental margin (locality 21 [Gogo], Fig. 1A), or in the Lachlan Fold Belt in the eastern part of the continent (localities 1 [Mount Howitt], 2 [Buchan], 5 [Taemas, Wee Jasper], 7 [Canowindra], Fig. 1A). These areas were subject to repeated marine incursions during the Palaeozoic. From

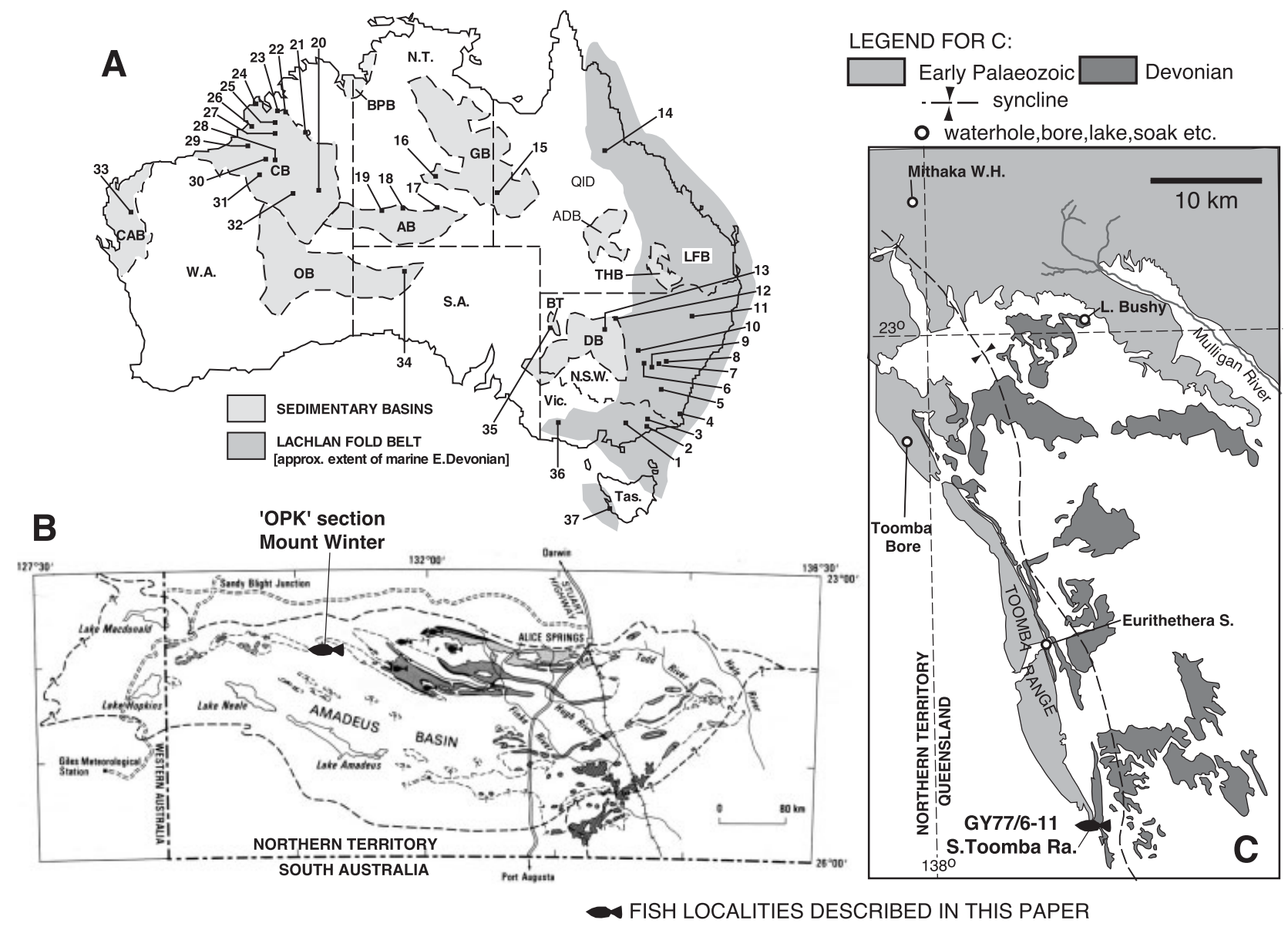

Fig. 1. A - Locality map for Devonian vertebrate occurrences in Australia (modified from Young \& Turner 2000). Material described in this paper comes from the Amadeus Basin (AB, locality 19) and the Georgina Basin (GB, locality 15). For full explanation of locality numbers and abbreviations see Young \& Turner (2000). B - Devonian rocks in the Amadeus Basin, showing the location of the OPK ('Orange Peel Knob') measured section at Mt. Winter (locality 19, Fig. 1A). C - Devonian rocks of the Cravens Peak Beds (dark grey) in the Toko Range - Toomba Range area, Georgina Basin (locality 15, Fig. 1A). 
the central part of the Australian craton, Devonian fish remains (placoderms) were first described by Hills (1959) from the Georgina Basin (locality 16 [Dulcie Range], Fig. 1A), and Gilbert-Tomlinson (1968) reviewed all known occurrences, which were mainly placoderm remains (a 'possible dipnoan fragment' from the Georgina Basin was an erroneous determination; Young \& Goujet 2003: 66). The first indication of a diverse osteichthyan fauna was an associated lungfish skull and rhipidistian remains documented by Young (1985) from the central Macdonnell Ranges of the Amadeus Basin (locality 18 [Stokes Pass], Fig. 1A). From the Georgina Basin (localities 15 [Toomba Range], 16 [Dulcie Range], Fig. 1A), Young \& Goujet (2003) have recently documented incomplete remains provisionally assigned to three osteichthyan groups (onychodontids, porolepiforms, rhizodontids).

In this paper we describe some osteichthyan remains from two central Australian localities presumed to be about the same age (Emsian-Eifelian): Mt. Winter in the western Amadeus Basin, and the southern Toomba Range in the Georgina Basin (localities 19, 15, Fig. 1A). These are the first named osteichthyans from the Devonian of central Australia, and the first described forms from the Mt. Winter locality.

\section{Field occurrences}

\section{A. Mount Winter, western Amadeus Basin (locality 19, Fig. 1A)}

Field work near Mount Winter in the western part of the Macdonnell Ranges in 1991 (G. C. Young and S. Turner) led to discovery of a diverse assemblage of micro- and macrovertebrate remains in a calcareous sandstone-siltstone sequence $20-30 \mathrm{~m}$ above a fossil fish plate occurrence at the top of the Mereenie Sandstone. The measured section at this locality, briefly described by Young \& Turner (2000: 464), is presented with lithological and palaeontological marker beds and sample numbers in Figure 2A. The base of the Mount Winter section is a fragmentary placoderm horizon from the transition beds between the Mereenie Sandstone and the overlying Pertnjara Group, provisionally assigned to the Wuttagoonaspis assemblage (Young \& Turner 2000: 464). The main evidence is a spinal plate assigned to Wuttagoonaspis from a nearby locality illustrated by Young (1988: fig. 13). The main fossil fish interval is overlain by a lime- stone unit some $30 \mathrm{~m}$ thick, and at the $60 \mathrm{~m}$ level sandstone-siltstone interbeds mark the return to a clastic sequence interpreted as the base of Harajica Sandstone equivalents (Young \& Turner 2000: fig. 4, column C). However, in the type section for the Parke Siltstone in the central Macdonnell Ranges (locality 18, Fig. 1A), summarised in Figure 2B, the basal Deering Siltstone Member beneath the Harajica Sandstone Member is considerably thicker $(200 \mathrm{~m})$, so these lithological correlations are only approximate (for details of Pertnjara Group geology see Wells et al. 1970; Jones 1972, 1991).

\section{B. Southern Toomba Range, Georgina Basin (locality 15, Fig. 1A)}

Young \& Turner (2000: fig. 4, columns C, E) compared the Mount Winter section just discussed with that for the Cravens Peak limestone unit in the Georgina Basin. This limestone was originally assumed to have a conformable and basal position beneath the Wuttagoonaspis assemblage (hence termed the 'basal calcareous unit'). A diverse fish fauna including Wuttagoonaspis is well represented in associated sandstone lithologies of the Cravens Peak Beds (Fig. 1C), as recently described by Young \& Goujet (2003). The only known Devonian limestone outcrop was initially assumed to be of Ordovician age, but sampling for microfossils revealed an assemblage of Devonian fish scales (thelodonts and acanthodians), first described by Turner et al. (1981). Further collecting of macrovertebrate remains (Young 1977) revealed a fauna including antiarch placoderms (Young 1984) and teeth of the chondrichthyan Mcmurdodus (Turner \& Young 1987). Turner (1995) revised the thelodonts, and noted associated shark scales, onychodont teeth, sarcopterygian scales, lepidotrichia, and acanthodian remains. The acanthodians are described by Burrow \& Young (2005), and include a new genus and two new species, based on disarticulated fin spines, scales, and a perichondrally ossified palatoquadrate and scapulocoracoids.

Turner (1991) and Young (1993) noted that the microvertebrate assemblages described by Turner et al. (1981) contained conflicting evidence of age, and Young (1995: 20) discussed the possibility that the assemblage may have mixed material from older (shot-point samples) and younger (outcrop) horizons. Young (1996: 103) considered the fauna attributed to the 'basal cal- 
careous unit' of the Cravens Peak Beds to include a component which was younger (?Eifelian) than the Early Devonian age assigned by Turner et al. (1981). Of the eight taxa first documented from this 'basal calcareous unit', five were listed by Turner et al. (1981: fig. 4) as common to the limestone and shot-point samples. Subsequently the two thelodonts from the former were reassigned to a new species by Turner (1995). The best preserved illustrated ostracods (Healdianella and Bashkirina?) only come from the shot-point samples, and the eridostracan Cryptophyllus is best represented only from the limestone sample (Turner et al. 1981: fig. 15). Gi- ven the possibility that different levels may have been sampled, the poorly preserved unfigured remains of these crustacean taxa are in need of restudy (P. J. Jones, pers. comm.). Because of this uncertainty, Young \& Turner (2000: fig. 4, column E) gave alternative late Pragian-Emsian, or late Emsian-Eifelian, ages for this assemblage, which was provisionally assigned to microvertebrate assemblage zone MV6 in the macrovertebrate (MAV) and microvertebrate (MV) biostratigraphic scheme for East Gondwana proposed by Young (1995, 1996; updated summary in Young \& Turner 2000: fig. 2). The two alternative stratigraphic positions for the 'basal calcar-

\section{AMADEUS BASIN, W. SECTION 'OPK' section, Mount Winter}

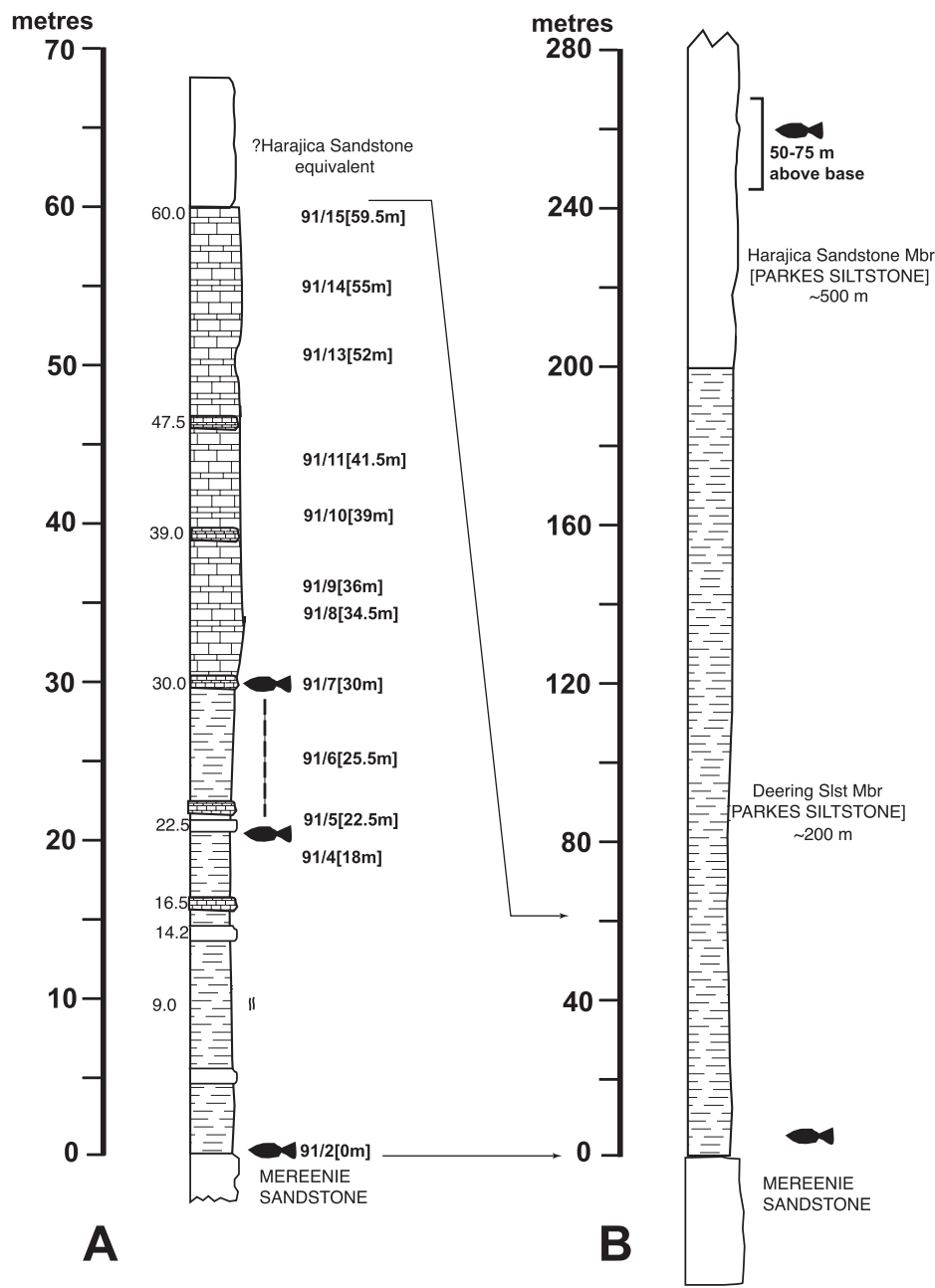

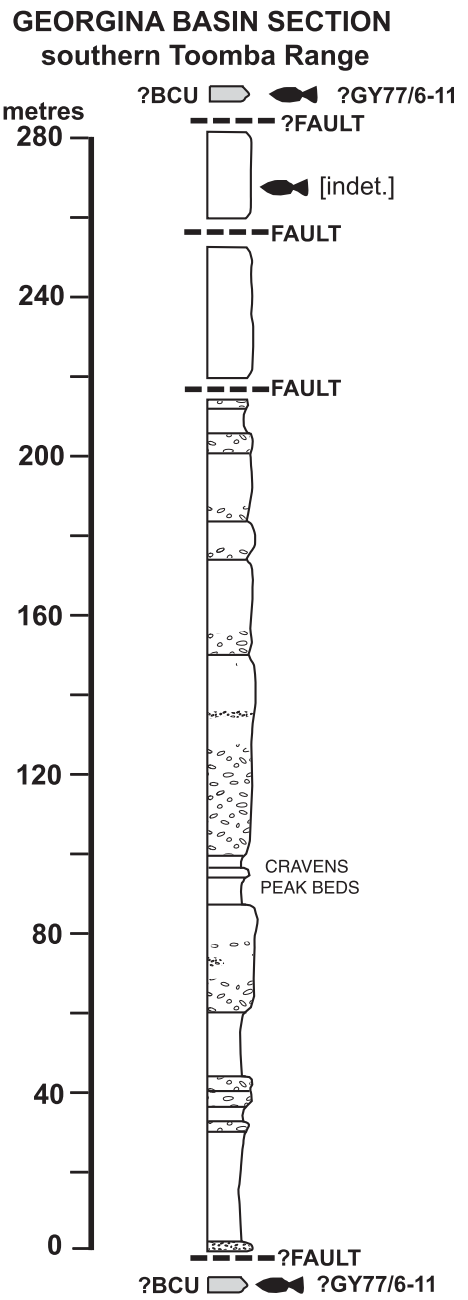

C

Fig. 2. Summary stratigraphic sections at three localities across central Australia. A - 'OPK' section, Mt. Winter (locality 19, Fig. 1A, B). All Amadeus Basin material described here comes from the horizon $30 \mathrm{~m}$ above the base in this section. $\mathbf{B}-$ Type section for the Devonian Pertnjara Group at locality 18 in the Amadeus Basin (Fig. 1A). The upper fish fauna (?Givetian; 50-75 m above the base of the Harajica Member) is documented by Young $(1985,1988,2005)$. C - Southern Toomba Range (locality 15, Fig. 1A), showing the measured section of Draper (1976) through the Cravens Peak Beds, with two possible stratigraphic positions for the 'basal calcareous unit' (BCU), depending on interpretation of geological faults. All Georgina Basin material described here comes from the only known limestone outcrop attributed to this unit (field localities GY77/611, Fig. 1C). The fish fauna in sandstones of the Cravens Peak Beds is documented by Young (1991) and Young \& Goujet (2003). 
eous unit' (BCU) are indicated on the stratigraphic section in Figure 2C. Turner $(1995,1997)$ compared the thelodonts with younger (Middle Devonian) turiniid scales from the Broken River sequence of Queensland and the Aztec sequence of Victoria Land, Antarctica. The acanthodian assemblage also indicates a mixing of older and younger elements in the fauna (Burrow 2002; Burrow \& Young, 2005).

The few osteichthyan remains described below were collected from the only surface outcrop of limestone, and are assumed to belong to the younger component in the assemblage. A $280 \mathrm{~m}$ thick measured section of Cravens Peak Beds only $100 \mathrm{~m}$ from the limestone outcrop begins with a basal pebbly unit first assumed to overlie it (Turner et al. 1981: fig. 3), but a faulted contact noted in the original field assessment (Draper 1976: fig. 4, section 1) places some uncertainty on the stratigraphic relationship. Many localities in the adjacent sandstone lithology have yielded a diverse fish assemblage (Young 1991; Young \& Goujet 2003). Young \& Goujet (2003) discussed the geological evidence in more detail, and concluded that the Wuttagoonaspis fauna from the Cravens Peak Beds and lower Dulcie Sandstone in the Georgina Basin was probably no older than Pragian, and no younger than early Eifelian, but a more precise age assessment was not possible. Full systematic documentation of the faunas involved will clarify the age relationships, and the description of osteichthyans presented in this paper is a contribution to that result.

\section{Material and methods}

All specimens are housed in the Department of Earth \& Marine Sciences, Australian National University, Canberra (ANU V). Material from the Mount Winter locality was prepared mechanically, and that from the Georgina Basin was etched in acetic acid. ANU V2969, a small onychodont lower jaw acid-prepared in 2001 in the palaeontological laboratory of the Museum für Naturkunde, Berlin, has produced a range of other taxa in the residues which are described below (acanthodian remains described by Burrow \& Young 2005). Measurements for osteolepidid skull remains follow Jarvik (1948), as updated by Jarvik (1985: fig. 2).

\section{Systematic palaeontology}

Class Osteichthyes Huxley, 1880

Subclass Sarcopterygii Romer, 1955

Infraclass Dipnoiformes Cloutier in Schultze, 1992a

Order Dipnoi Müller, 1845

Family incertae sedis

\section{Amadeodipterus n. gen.}

Diagnosis: A short-headed dipnoan (interorbital distance nearly as wide as the skull is long) with a B-bone broader than long. Bones $\mathrm{A}$ and $\mathrm{H}$ enclosed in the skull roof; short C-bones; large, possibly unpaired E-bone; bone I larger than bone $\mathrm{J}$.

Type species: Amadeodipterus kencampbelli n. sp.

Age: Early/Middle Devonian.

Derivatio nominis: After the Amadeus Basin, a major Palaeozoic sedimentary basin of central Australia, from Lake Amadeus, first named in 1872 by the explorer Ernest Giles in honour of his benefactor Baron Ferdinand von Müller, who later apparently insisted that King Amadeus of Spain be honoured instead of himself; combined with dipterus, name used for many Devonian lungfish.

\section{Amadeodipterus kencampbelli n. sp.}

Figs 3A, 4, 5A

1993 'dipnoans (?dipterid)' - Young: 223

2000 'dipnoan remains' - Young \& Turner: 464.

Diagn osis: See diagnosis of genus.

Holotype: ANU V2709, an incomplete skull roof.

Additional material: ANU V2708 (left pterygoid tooth plate with bones J, K, L, X and 3); ANU V2960 (right pterygoid tooth plate with bones K, L and 3); ANU V3037 (indeterminate bone portion); ANU V2968 (incomplete branchiostegal or subopercular); ANU V3036, V3038 (scales with Westoll lines).

Locality and Age: $30 \mathrm{~m}$ above the base of the 'OPK' section (see Fig. 2A), about $3.7 \mathrm{~km}$ northwest of the summit of Mount Winter, Amadeus Basin, central Australia (Fig. 1A, B; southwestern corner of the Mount Liebig 1:250000 sheet, see Scrimgeour et al. 2005): Emsian - Eifelian.

Derivatio nominis: To acknowledge the major contribution to the study of Palaeozoic lungfishes by Professor Ken Campbell, Australian National University, Canberra.

Description: The holotype (Fig. 3A) is an incomplete portion of a skull roof about $33 \mathrm{~mm}$ long. It is notable for the very asymmetrical shape and arrangement of bones of the left and right sides (Fig. 4A, B). The two additional skull specimens add to the total variability of the skull roofing bones. All bones in the holotype are covered with cosmine, which is weathered in some posterior central parts to expose canals of the pore canal system (Fig. 3A). Normally one Westoll line follows the outer contour line of each bone. A unique feature of this skull is that bone $\mathrm{A}$ is incorporated within the skull roof (Fig. 4A, B), a condition seen in no other lungfish. Not only is it sutured with bones $\mathrm{B}$ and $\mathrm{I}$, but bone $\mathrm{A}$ is bounded by bone $\mathrm{H}$ through a posteromediad running suture, clearly seen on the left side of the posterior preserved margin (Fig. 3A). Another unusual feature is the proportion of the B-bone, which is wider than long $(114 \%)$, rather than longer than wide 
as in other Devonian lungfish. This bone has straight borders posteriorly and laterally, forming sutures with bone $\mathrm{A}$ and the paired I-bones. The lateral and anterolateral borders of bone B are more irregular. A group of four smaller bones, two median and two lateral ones, lie in the midline in front of bone $\mathrm{B}$. The lateral bones are interpreted as C-bones; the median bones may be called $\mathrm{C}^{\prime}$ - or $\mathrm{D}^{\prime}$-bones, with only the anterior median bone ( $\mathrm{D}^{\prime}$, Fig. 4A) approaching the normal position of bone $\mathrm{D}$ (between C- and E-bones as seen in other lungfish skulls). There are no complete bone sutures in front of the $\mathrm{C}$ - and D-bones. The large central bone with sutures to C-, $\mathrm{D}^{\prime}$ - and J-bones posteriorly and to LM- and KLM-bones laterally may represent a large unpaired E-bone.

On the left side of the posterior preserved margin a square $\mathrm{H}$-bone lies lateral to bone A (its posterior and lateral margins are abraded, but apparently complete). It has some pores of the lateral line system, also seen on the lateral part of the left I-bone in front. This bone is wider than long, whereas the I-bone of the right side appears longer than wide, but is incomplete. There are no pores on its preserved part. The left I-bone is expanded laterally, and shorter medially, whereas the right I-bone has a longer medial suture with bone $\mathrm{B}$. A square bone $\mathrm{J}$ and a large bone $\mathrm{X}$ occupy the space in front of the left I bone. The square J-bone may only represent part of bone J, with its anterior part perhaps fused with bone $\mathrm{K}$. Alternatively, bone K may have taken over the anterior space of bone $\mathrm{J}$ (labelled KJ in Fig. 4B). Bones X and K on the left side show no external pores of the lateral line system. The left bone LM is longer than wide. The large median bone has its continuation anteromediad to the snout, with an evagination with an overlap area for the missing bones of the anterior left side.

The right side of the holotype shows a different bone pattern. The anterior extension of bone I separates bone $\mathrm{J}$ from bone $\mathrm{X}$. Bone $\mathrm{J}$ has otherwise the normal relationship to surrounding bones $\mathrm{I}, \mathrm{B}, \mathrm{C}$ and $\mathrm{K}$. It reaches anteriad to the anterior level of bone $\mathrm{C}$, and thus completely separates bone $\mathrm{C}$ from bones $\mathrm{K}$ and $\mathrm{L}$. In contrast to the left side, there is a long bone lateral to the right J-bone, which carries the supraorbital canal as indicated by the many sensory pores. This long bone represents the space of bones $\mathrm{K}+\mathrm{L}+\mathrm{M}$. Bones $\mathrm{X}, 3$ and $\mathrm{O}$ lie lateral to it, with many sensory pores on the X-bone (incompletely preserved). The left bone $\mathrm{X}$ borders bones I, $\mathrm{J}$ and $\mathrm{KJ}$. The anterior bone in front of bone 3 is not preserved. The bone $Y_{1}$ must have attached laterally because the posterior border of bone $\mathrm{X}$ sutures with bone I. The right $\mathrm{X}$-bone shows many pores of the sensory line whereas these are missing on the left side. The preserved anterior part of the right X-bone borders bones $\mathrm{I}$, KLM and 3. It is separated from $\mathrm{J}$ by a posterior process of bone KLM and an anterior process of bone I. Bone 3 is positioned between bones $\mathrm{X}$ and $\mathrm{O}$. Its anterolateral corner is broken, so the margin of the orbit is only preserved for a short distance.

No traces of pit lines were observed on any part of the skull.

Two other pieces of skull, each with parts of the pterygoid tooth plates attached, show even more variability in the arrangement of skull roofing bones. Bones $\mathrm{K}$ and $\mathrm{L}$ form separate bones in both specimens (Fig. 4C, D). Bone $\mathrm{K}$ has many pores of the supraorbital canal, which are lacking on the left side of the more complete skull roof of the holotype. In ANU V2708 (Fig. 4C) bone $\mathrm{K}$ is surrounded by bones J, X, 3, and $\mathrm{L}$, but all are only partly preserved. Bone 3 is the most complete preserved bone in ANU V2960 (Fig. 4D).

The skull roof is broad, broader than in other lungfish (even broader than the skull of Chirodipterus). The reconstruction of the skull roof (Fig. 4E) requires two small Y-bones lateral to bone I and without contact to bone J. Still bone $\mathrm{Y}_{1}$ may have contact to bone $\mathrm{J}$ in ANU V2708 (Fig. 4C). Bone $\mathrm{Z}$ lies lateral to bone $\mathrm{H}$ as in other Early Devonian lungfish and has no contact to bone A. The supraorbital canal ends in bone $\mathrm{X}$, where the temporal canal splits into infra- and supraorbital canals.

The pterygoid tooth plates of ANU V2708 and V2960 have at least 15 tooth ridges. They are strongly weathered, so it is difficult to give a good description. The ridges radiate anteriad, lateral and posterolateral from a point close to the midline, in contrast to Tarachomylax and Stomiahykus, for example, where the ridges radiate anteriad from a posterior point at the posterior margin of the toothplate. The tooth plates meet in midline. The teeth are smaller and closer together on the posterior ridges. These are typical tooth plates of dipterid type, which are otherwise first recorded from the Lower Devonian (Barwick et al. 1997).

ANU V2968 is an incomplete lungfish subopercular showing an anterodorsally pointing cosmine cover with one surrounding Westoll line 
and wide bony overlapped dorsal and anterior margin.

Another bone fragment (ANU V3037) shows the posterior part of a $15 \mathrm{~mm}$ broad bone with straight lateral margins sutured with narrow bone pieces. A Westoll line follows the margins, a second one is placed away from the margin, and a third close to the centre. This bone may be a B-bone of the skull.

Isolated dipnoan scales from the same locality (ANU V3036, V3038) are up to $14 \mathrm{~mm}$ across, and thus from a much larger fish than the skull remains, but assumed also to belong to Amadeodipterus kencampbelli $\mathrm{n}$. $\mathrm{sp}$. These are round scales with cosmine cover and Westoll lines. They show tubercles with shallow depressions on their top face (Fig. 5A). Such scales are described from Iowadipterus (Schultze 1992b: fig. 9A) and from Tarachomylax (Barwick et al. 1997: fig. 6) within dipnoans, and from holoptychiid rhipidistians. The free field is covered with small pores as in Tarachomylax. These scales
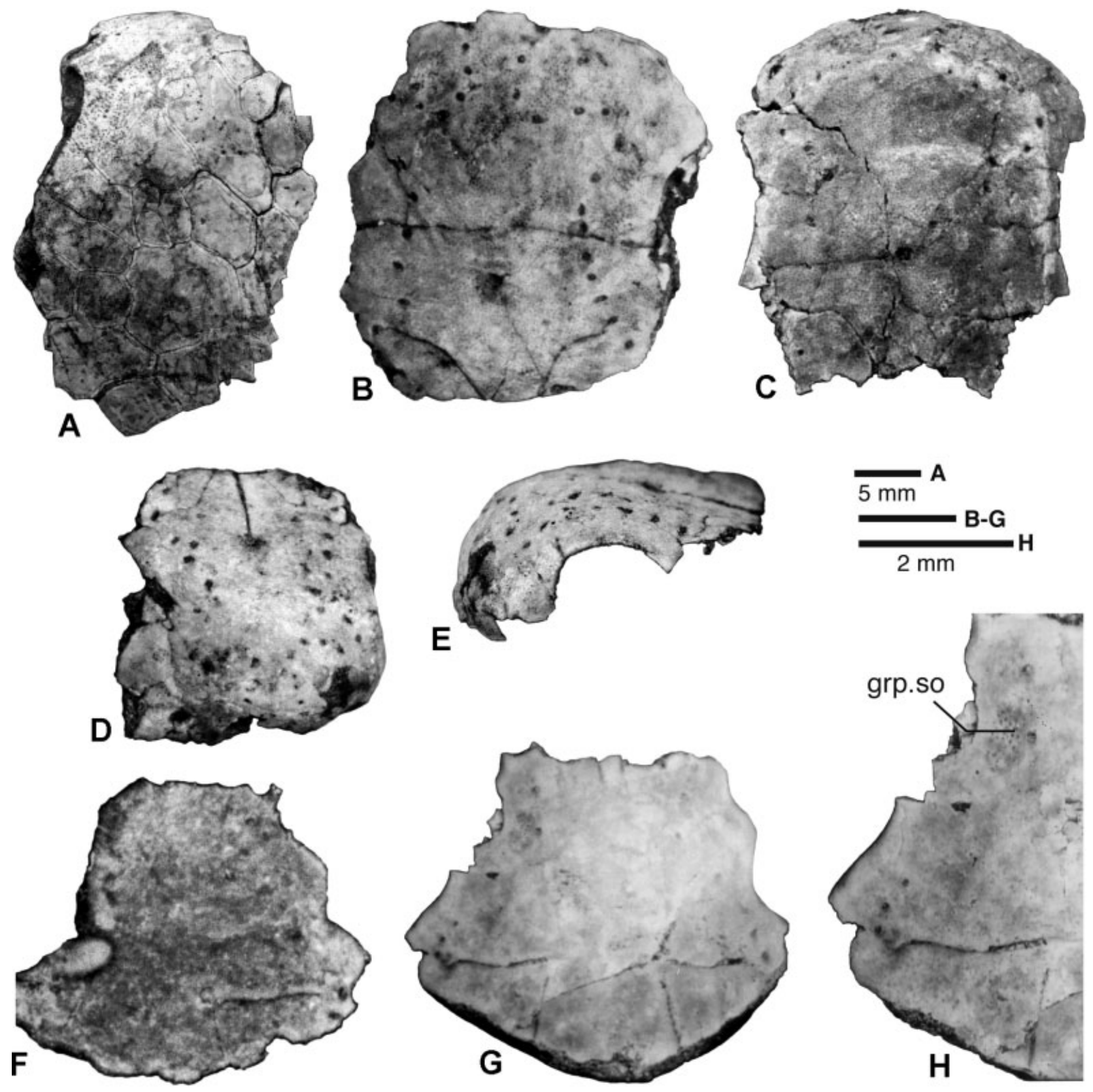

Fig. 3. A - Skull roof of Amadeodipterus kencampbelli n. gen., n. sp., dorsal view (holotype, ANU V2709); B-H - Muranjilepis winterensis n. gen., n. sp.; B, C - Parietoethmoidal shields in dorsal view (ANU V2961, 2963); D, E - Parietoethmoidal shield in anterodorsal and left lateral views (ANU V2962). F, G - Postparietal shields in dorsal view (ANU V2964, 3035); H - Detail of ANU 3035, showing sensory pores. All specimens from near Mt. Winter, Amadeus Basin, central Australia (locality 19, Fig. 1A); grp.so - pore groups indicating cutaneous sensory organs. 

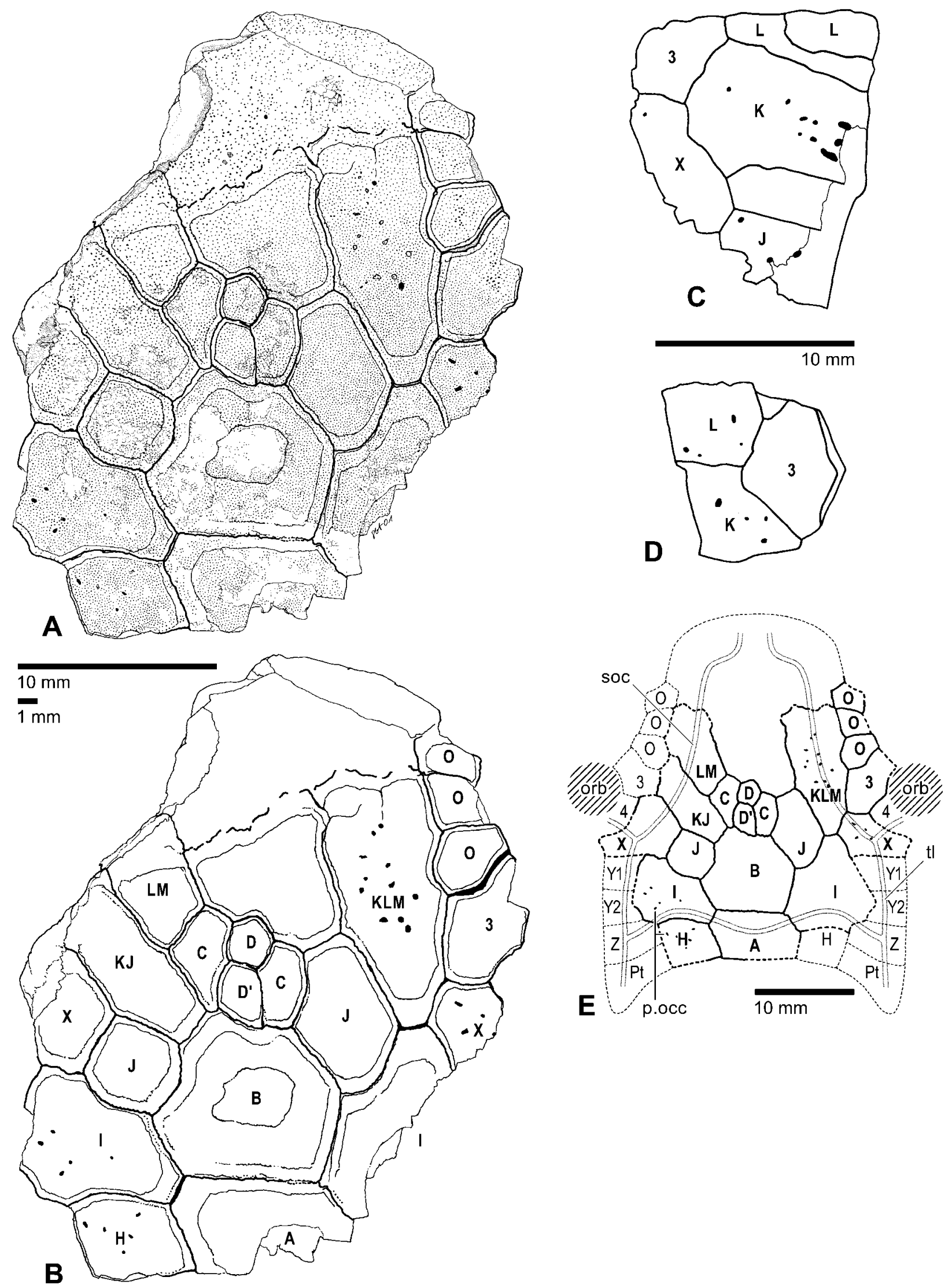

Fig. 4. A, B - Preserved skull roof pattern of Amadeodipterus kencampbelli n. gen., n. sp., dorsal view (holotype, ANU V2709); B - Interpretation of the skull roof pattern; C - Drawing of ANU V2708, left lateral portion of skull roof; D Drawing of ANU V2960, right lateral portion of skull roof; E - Attempted skull roof restoration, based on holotype. Mt. Winter, Amadeus Basin, central Australia (locality 19, Fig. 1A). A, B, C, D, D', H, I, J, K, KJ, KLM, L, O, X, Y, 2, Z, 4, 3 dipnoan skull roofing bones; orb - orbit; p.occ - pores of the occipital commissure; p.tl - pores of the temporal canal; soc supraorbital canal. 
may be contrasted with isolated scales from the Toomba Range locality described below, which lack the broad field of tubercles, and have the free field covered by fine ridges (Fig. 5B-F).

Comparisons: Taken together, these incomplete dipnoan specimens show considerable disparity in the arrangement and shapes of skull bones. However, given the variability of the skull pattern in other dipnoans there is no reason on available evidence not to place them in the same taxon. The size difference between left and right bones $I$ and $J$ is rare in lungfish. Westoll (1949) and Parrington (1950) figured such differences in Dipterus valenciennesi (Westoll 1949: fig. 2B; right side with two I-bones, figs 3E, 4D; lack of bone $\mathrm{J}$ on one or both sides). Schultze \& Bolt (1996: fig. 2C) showed two J-bones and a wide Ibone on the left side in Tranodis. The bone ser-

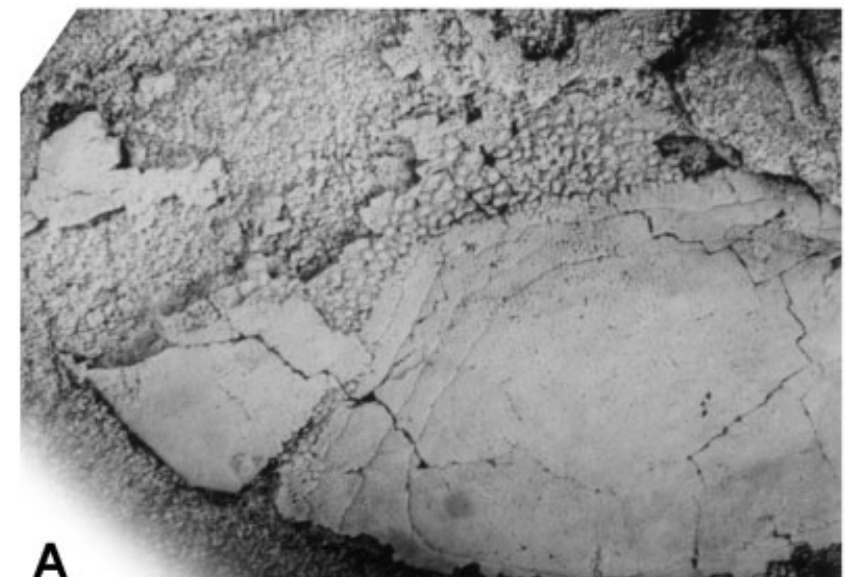

A
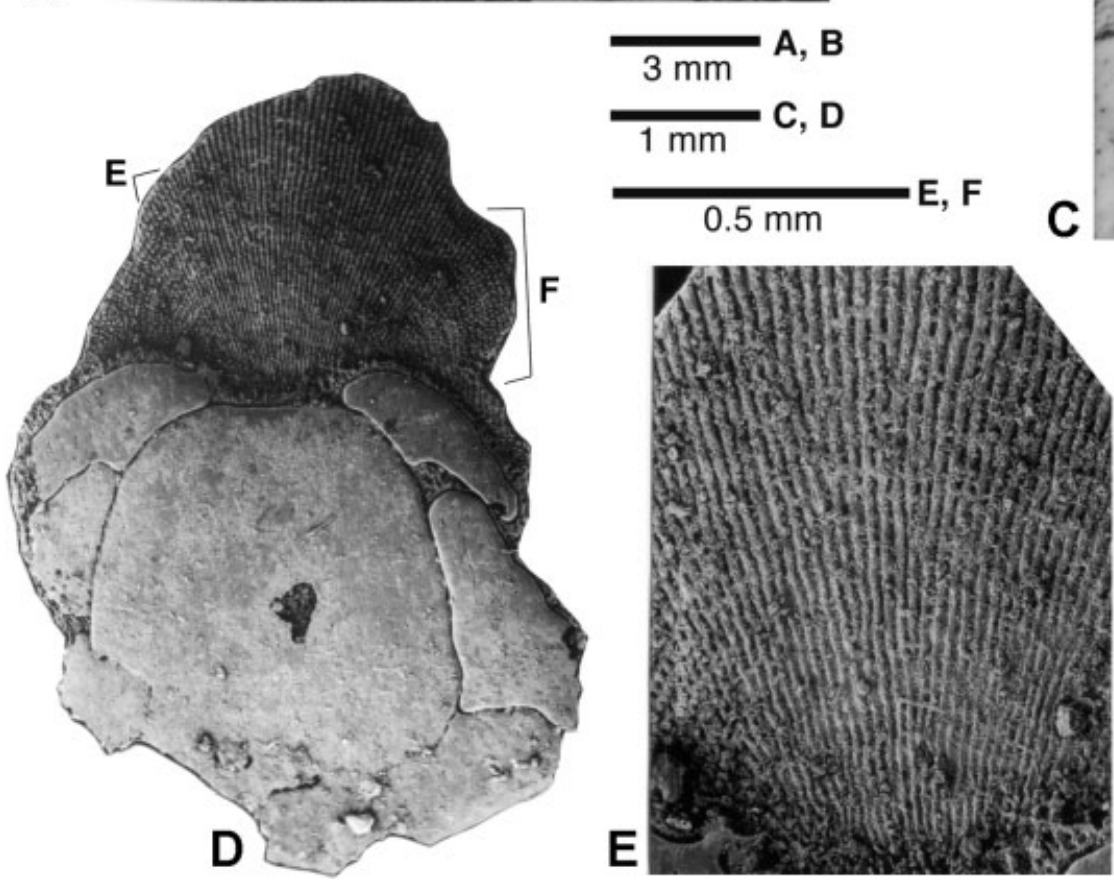

Fig. 5. Various isolated dipnoan scales in external view. A - ANU V3038 from Mt. Winter, Amadeus Basin, central Australia (locality 19, Fig. 1A); B-F - Scales from Toomba Range, Georgina Basin, central Australia (locality 15, Fig. 1A); B, C ANU V3087; D-F - ANU V3086. ies along the supraorbital canal is also very variable in dipnoans (Cloutier 1997; Schultze \& Bolt 1996; Kemp 1999), and this new form is no exception. A bone $\mathrm{D}^{\prime}$ is also known from Dipterus (White 1965: figs. 19, 25), Tranodis (Schultze \& Bolt 1996: fig. 2D) and other dipnoans (Kemp 1999: table 6).

The enclosure of bones $\mathrm{A}$ and $\mathrm{H}$ into the skull table is unique for the new genus, whereas the separation of bone A from bone $\mathrm{Z}$ by bone $\mathrm{H}$ is a primitive feature, reconstructed in Uranolophus, Dipnorhynchus, Westollrhynchus, and present in Chirodipterus, Griphognathus, and Rhinodipterus. Bone $\mathrm{H}$ lies behind bones $\mathrm{Z}$ and $\mathrm{A}$ in Dipterus. Unusual for lungfish is the broad Bbone; bone B broader than long is otherwise only recorded in one specimen of Scaumenacia (Cloutier 1997: fig. 7B).
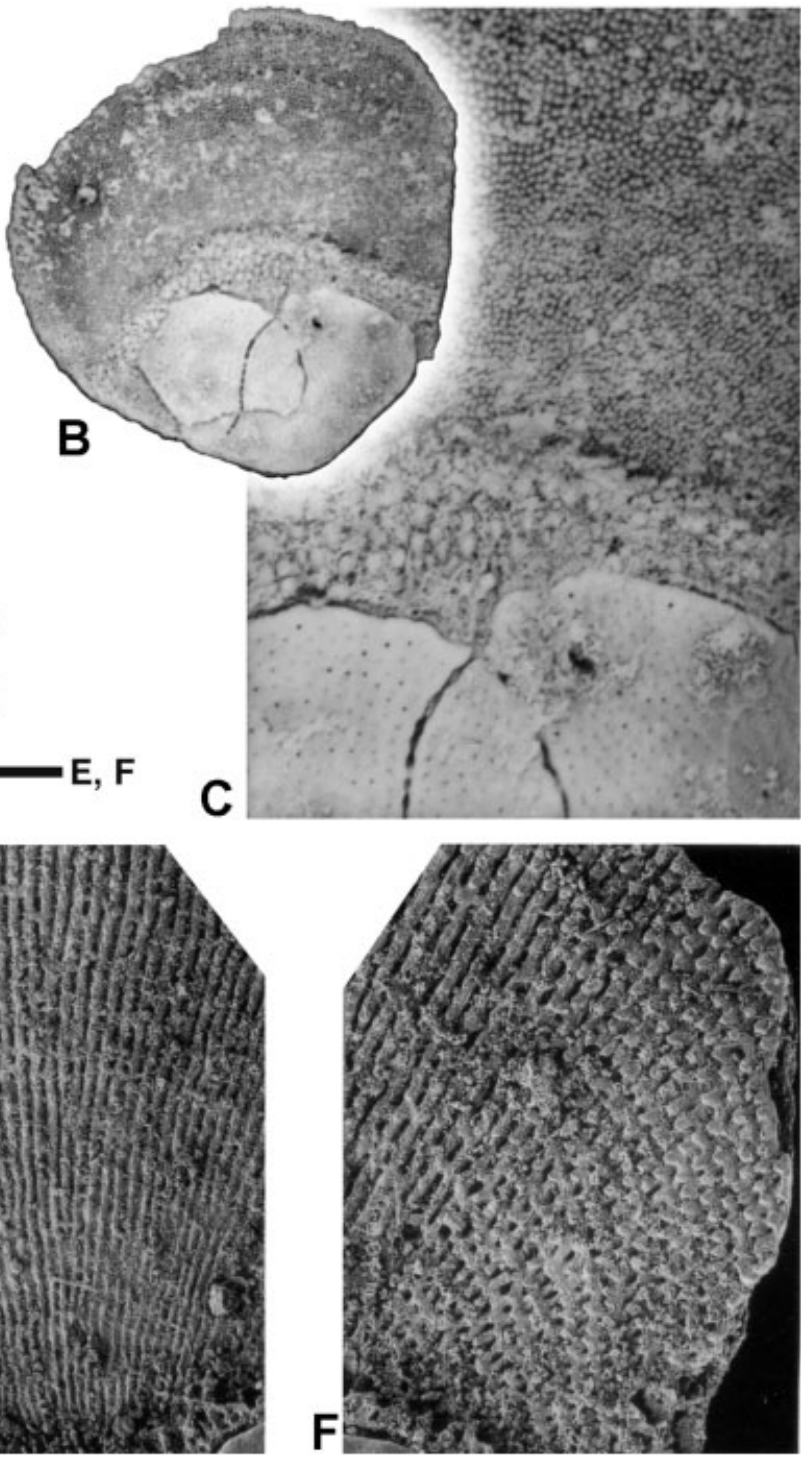
The possession of true lungfish tooth plates and the branching of supra- and infraorbital canal from the temporal canal in bone $\mathrm{X}$ places the new genus above node 6 in the cladogram of Schultze (2001), and the scale structure, as in Iowadipterus and Tarachomylax, is consistent with this (both genera also above node 6).

\section{Dipnoi gen. et sp. indet.}

Fig. 5B-F

1984 'dipnoan remains' - Young: 66.

2000 'possible dipnoan' - Turner et al.: 502.

2003 'dipnoan remains' - Young \& Goujet: 66.

Material: Isolated scales (ANU V3086-3097).

Locality and Age: Southern part of the Toomba Range, western Queensland, approximate latitude $23^{\circ} 23^{\prime} 47^{\prime \prime} \mathrm{S}$, longitude $138^{\circ} 08^{\prime} 10^{\prime \prime} \mathrm{E}$ (Abudda Lakes 1:100 000 sheet); horizon uncertain (?BCU, Fig. 2C); Emsian - Eifelian.

Description: Eleven round dipnoan scales were extracted from the residue of ANU V2969, and one similar scale (Fig. 5D) was scanned on the electron microscope by Dr. C. Burrow from a sample provided for etching to Dr. S. Turner. These scales show cosmine cover on the free field, with some Westoll lines; four of the scales carry a pit line. The free field descends abruptly to the covered field. There are few tubercles visible on a narrow field anterior to the cosmine cover (Fig. 5C). The covered field is characterised by radial, finely serrated ridges (Fig. 5E), with a texture that is much more linear than in the 'honeycomb' structure of the covered field illustrated for Gogo dipnoans (e.g. Pridmore \& Barwick 1993: fig. 13).

These scales can be distinguished from the smaller isolated scales of Amadeodipterus kencampbelli $\mathrm{n}$. sp. described above by the ridges of the anterior covered field, and the step between the free and covered field.

Infraclass Rhipidistia Cope, 1887

Order Osteolepidida Boulenger, 1901

Family Osteolepididae Cope, 1889

\section{Muranjilepis n. gen.}

Diagnosis: A small osteolepidid with a very short and wide postparietal shield, large orbits compared to parietoethmoidal length, very short preorbital length, large pores of the sensory line system, supraorbital lines forming an excessive lateral extension in front of orbits, downwards arched snout, and marginal position of anterior external naris. Lacrimal notch is separated from notch for anterior tip of maxilla.

Type species: Muranjilepis winterensis n. sp.
Derivatio nominis: After Muranji Rockhole, an important water source for the original Aboriginal inhabitants of the desert (located in the base of the Mereenie Sandstone, $5 \mathrm{~km} \mathrm{NNW}$ of the summit of Mount Winter, and about $2 \mathrm{~km}$ $\mathrm{N}$ of the type locality).

\section{Muranjilepis winterensis $\mathbf{n} . \mathbf{s p .}$} Figs 3B-H, 6, 7

1993 'osteolepids' - Young: 223. 2000 'osteolepid remains' - Young \& Turner: 464.

Diagnosis: See diagnosis of genus.

Holotype: ANU V2961 (parietoethmoidal shield).

Additional material: Three parietoethmoidal shields (ANU V2962, 2963, 2967); five postparietal shields (ANU V2964, 2965, 2966, 3035, 3098).

Locality and Age: $30 \mathrm{~m}$ above the base of the 'OPK' section (see Fig. 2A), about $3.7 \mathrm{~km}$ northwest of the summit of Mount Winter, Amadeus Basin, central Australia (Fig. 1A, B; southwestern corner of the Mount Liebig 1:250000 sheet, see Scrimgeour et al. 2005); Emsian - Eifelian.

Derivatio nominis: After Mount Winter, the locality where the material was found.

Description: These nine examples of osteolepidid shields are all of similar small size (7$8 \mathrm{~mm}$ length), and covered completely by cosmine, obscuring most bone sutures. Measurements and proportions are summarised in Table 1 .

On the parietoethmoidal shields (Fig. 3B-E), the median suture between the parietals posterior to the pineal opening is clearly visible only in ANU V2962 (Fig. 3D), which also shows a suture between the parietal and intertemporal, and possibly for the left premaxilla (Fig. 7A). The contact to the postparietal encompasses $66 \%$ of the length of the parietoethmoidal shield. The parietal pitline (pa.pl, Fig. 6B) in the posterior part of the parietoethmoidal shield forms a shallow arch from near the midline to the pores of the supraorbital sensory line behind the orbits (po.soc). The large pineal opening (pi) lies a third of the length of the parietoethmoidal shield in front of the contact with the postparietal shield and between the posterior parts of the rim of the orbit (orb). The posterior contact to the postparietal shield is nearly straight; a nearly straight line runs from the posterolateral corner to the postorbital corner. The dorsal orbital rim is well preserved in ANU V2961 and V2962 (Figs 3E, 6B, C). The orbit was relatively large, occupying about $40 \%$ of the length of the parietoethmoidal shield. The rounded preorbital corner (proc, Fig. 6B, C) separates the orbital notch from the lacrimal notch in front, which also shows a shallow overlap area for the anterior tip of the max- 
Table 1

Measurements and proportions of nine osteolepidid shields from Mt. Winter, Amadeus Basin, central Australia (locality 19, Fig. 1A) after Jarvik (1948). [e] = estimate based on one side to midline measurement.

\begin{tabular}{|c|c|c|c|c|c|c|c|c|c|c|c|}
\hline Spec. No. & $\mathrm{a}$ & $\mathrm{b}$ & $\mathrm{c}$ & $\mathrm{d}$ & $\mathrm{e}$ & $\mathrm{f}$ & $\mathrm{g}$ & $\mathrm{h}$ & $\mathrm{r}$ & $\mathrm{s}$ & $\mathrm{t}$ \\
\hline ANU V2961 & & 7.5 & 2.5 & $8[\mathrm{e}]$ & $6[\mathrm{e}]$ & $\sim 5$ & & & 2.5 & 3.5 & 1.5 \\
\hline ANU V2962 & & 6 & 2.4 & $7[\mathrm{e}]$ & 5.5 & $\sim 4$ & & & & & \\
\hline ANU V2963 & & 8.5 & $\sim 3$ & 7.5 & 6.5 & $\sim 4$ & & & & & \\
\hline ANU V2967 & & 7 & 2.9 & $\sim 7$ & & 4.5 & & & & & \\
\hline ANU V2964 & 5.5 & & & & & & 6.5 & 7.5 & & & \\
\hline ANU V2965 & 5 & & & & & & $\sim 4.4$ & $6[\mathrm{e}]$ & & & \\
\hline ANU V2966 & $\sim 7$ & & & & & & & & & & \\
\hline ANU V3035 & 7 & & & & & 4.5 & 6 & $\sim 9$ & & & \\
\hline ANU V3098 & $\sim 6.5$ & & & & & 4.5 & $\sim 6.5$ & 9 & & & \\
\hline
\end{tabular}

a - median length of postparietal shield; $\mathbf{b}$ - median length of parietoethmoidal shield; $\mathbf{c}$ - distance from center of pineal foramen to posterior margin of parietal; $\mathbf{d}$ - breadth of cranial roof at preorbital corner; $\mathbf{e}$ - breadth of cranial roof at the deepest point of the orbital notch; $\mathbf{f}$ - breadth of cranial roof at the deepest point of the postorbital notch; $\mathbf{g}$ - breadth of cranial roof at the spiracular notch; $\mathbf{h}$ - breadth of cranial roof at posterolateral corner of the postparietal shield; $\mathbf{r}-$ median length of preorbital division of parietoethmoidal shield; $\mathbf{s}$ - median length of orbital division of parietoethmoidal shield; $\mathbf{t}$ median length of postorbital division of parietoethmoidal shield.

illa. The lacrimal notch (la.n) is $45 \%$ the length of the orbit.

The pores of the supraorbital sensory canal (soc) are noteworthy for their relatively large size. They start close to the posterolateral corner of the parietoethmoidal shield, curve medially and then laterally inside the dorsal rim the orbit, and return in a sharp loop towards the midline in front of the orbit (Figs 6B, C, 7A). Close to the midline they turn anteriad and a little away from the row of the other side. The pores are not expressed so clearly on ANU V2967. A few depressions with pores larger than the normal cosmine pores probably correspond to the 'groups of pores probably transmitting nerves to groups of cutaneous organs' noted in the Scottish Middle Devonian osteolepidids by Jarvik (1948: 137-139).

Of the five postparietal shields, ANU V2964 and V3035 are best preserved. ANU V3035 shows an undulated anterior margin, with shallow invaginations for the parietals on each side of a short median process (Fig. 3G). Lateral to these, and separated by short processes, are two short invaginations marking the contact with the intertemporal. The right margin with two invaginations is complete, whereas the posterior and the left margin are broken. The anterior lateral invagination receives the postorbital, and the second marks the position of the spiracular slit. The anterior-posteriad running posterior pit-line and the medio-laterad running middle pit-line are preserved. The pores of the temporal sensory line appear close to the lateral margins, together with groups of pores probably for cutaneous sensory organs (Fig. $3 \mathrm{H})$.
ANU V2964 (Fig. 3F) is broader than long $(4: 3)$, and shows no sutures. As in the previous example, two pit-lines are developed, a short posterior and a long middle one (p.pl, m.pl, Fig. 7B). The left and right margins show the two invaginations for the postorbital and spiracular slit. The sensory line pores are as large as on the parietoethmoidal shield. ANU V2965 is distorted with an angled fracture along the midline, reducing original breadth between the two postparietals. ANU V2966 is broken through the midline so only the left side is incompletely preserved.

Taking into consideration the relatively large orbits and large pores of the sensory line system in these specimens, it is possible that the small size indicates remains of a juvenile, even though the disappearance of bone sutures contradicts such an interpretation.

Comparisons: The parietoethmoidal shield of this new taxon is more elongate, and the postparietal shield shorter and broader, than in Gyroptychius? australis described by Young \& Gorter (1981). The orbital position of the pineal opening is similar to that of Thursius and Osteolepis, and closest to Thursius pholidotus (Jarvik 1948), and Th. wudingensis Fan, 1992. The preorbital length is shorter and the postparietal shield broader and shorter than in all other described osteolepidids. A lateral loop of the supraorbital sensory canal is typical for osteolepidids (e.g. Jarvik 1948: figs 14, 32), but the extreme loop of this sensory line described above is seen also in Thursius wudingensis (Fan 1992: fig. 2B), and Kenichthys campbelli (Chang \& Zhu 1993: figs 2A, 3D). 

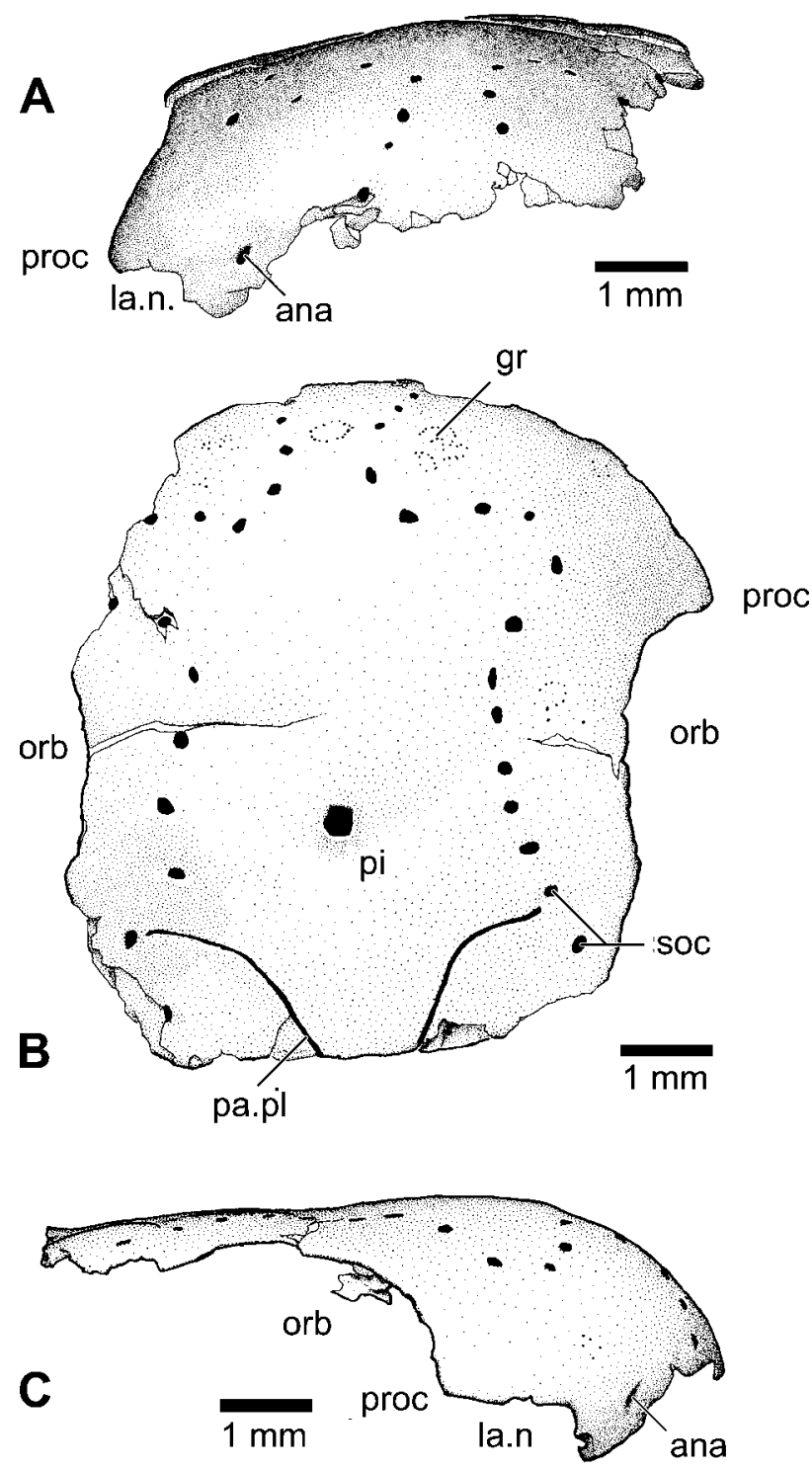

Fig. 6. Muranjilepis winterensis n. gen., n. sp., parietoethmoidal shield in anterior $(\mathbf{A})$, dorsal $(\mathbf{B})$ and right lateral $(\mathbf{C})$ views (holotype, ANU V2961). Mt. Winter, Amadeus Basin, central Australia (locality 19, Fig. 1A). ana - anterior external nasal opening; gr - vascular groove; la.n - lacrimal notch; orb - orbit; Pa - parietal; pa.pl - parietal pit line; pi - pineal foramen; proc - preorbital corner; soc - pores of the supraorbital sensory canal.

Chang \& Zhu (1993: 195) noted that the Chinese osteolepidid Kenichthys shares the greatest number of similarities with the Scottish form Gyroptychius, but differs in its very short and broad snout (the shortest amongst known osteolepidids), and its long postorbital division (the longest amongst known osteolepidids). In its very short, broad snout, grooved nasal opening, and deep embayment behind the postorbital corner, Kenichthys resembles G.? australis Young \& Gorter, 1981, the only previously described preLate Devonian osteolepidid from Australia. These are features not present in Muranjilepis winterensis n. gen., n. sp.

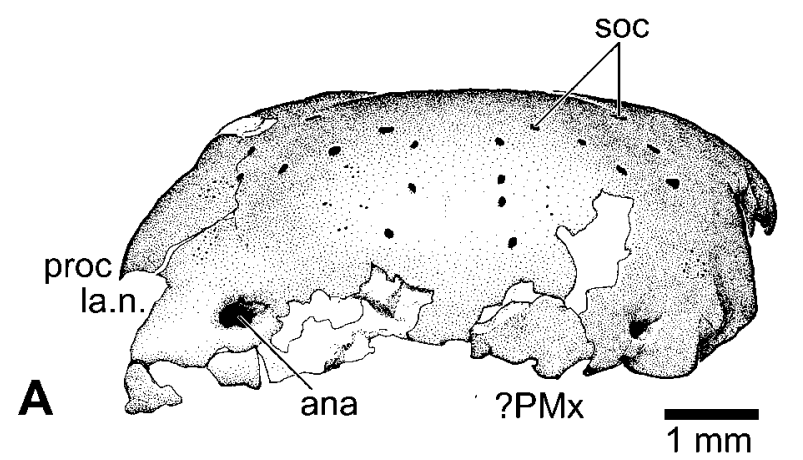

B

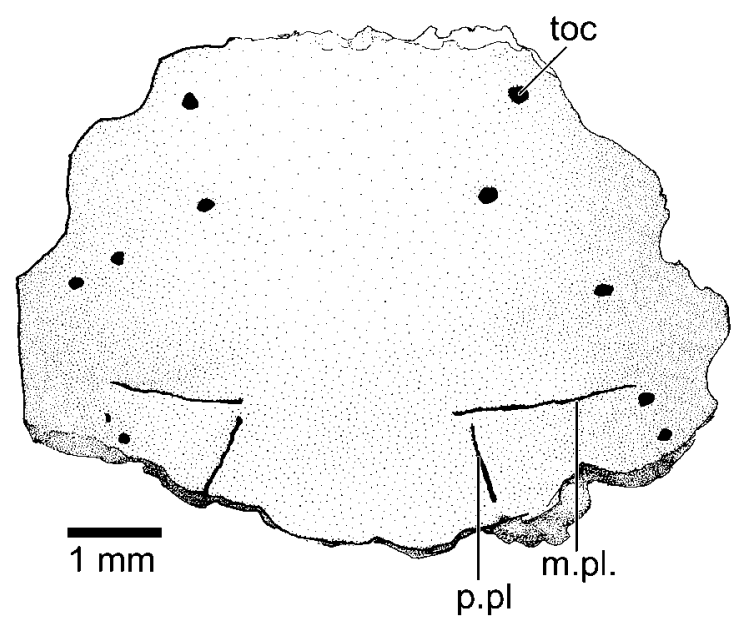

Fig. 7. Muranjilepis winterensis n. gen., n. sp. A - Parietoethmoidal shield in anterior view (ANU V2962); B - Postparietal shield in dorsal view (ANU V2964). Mt. Winter, Amadeus Basin, central Australia (locality 19, Fig. 1A). ana anterior external nasal opening; la.n - lacrimal notch; m.pl middle pit line; ?PMx - premaxilla; p.pl - posterior pit line; proc - preorbital corner; soc - pores of the supraorbital sensory canal; toc - pores of the temporal sensory canal.

osteolepidid n. gen., n. sp.

Figs 8, 9A-D

1987 'crossopterygian remains' (pars) - Turner \& Young: 233.

?1995 'scales of a sarcopterygian' (pars) - Turner: 683.

Material: Isolated scales (ANU V3099-3106).

Locality and Age: Southern part of the Toomba Range, western Queensland, approximate latitude $23^{\circ} 23^{\prime} 47^{\prime \prime}$ S, longitude $138^{\circ} 08^{\prime} 10^{\prime \prime} \mathrm{E}$ (Abudda Lakes 1: 100000 sheet); horizon uncertain (?BCU, Fig. 2C); Emsian - Eifelian.

Description: A small sample of eight similar scales of a new form of osteolepidid were extracted from the residue of ANU V2969. These scales were initially thought to belong to a palaeoniscid, because of the posterior serrations. However, under alcohol they revealed the cosmine and pore system. One example of a thick scale (Fig. 8A) shows the smooth cosmine surface with a finely serrated posterior border. The anterior border of the cosmine cover has leaflike extensions. The dorsal overlapped border 

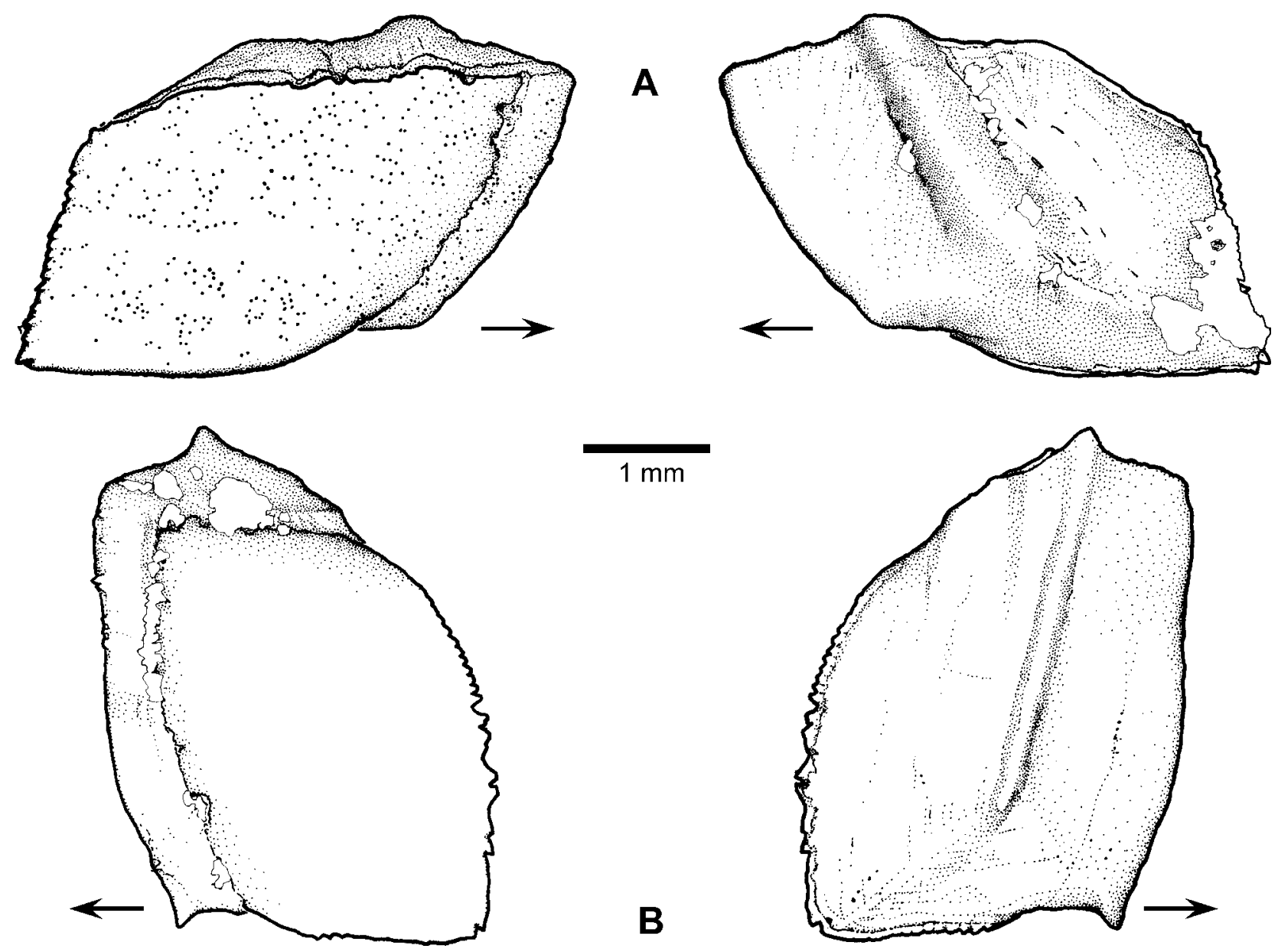

Fig. 8. Osteolepidid n. gen., n. sp. Two scales from the southern Toomba Range (locality 15, Fig. 1A), Queensland. A - ANU V3099; B - ANU V3100. External view on left; internal view on right; arrows point anteriad.

carries a small short-based peg. A ridge corresponding to the peg divides the inner surface into a short and a wide inner surface. This scale, and a second very similar example (Fig. 9A, B) may have come from the middle or posterior part of the flank. A second illustrated scale type (Fig. 8B) has a higher rhombic shape, and is evidently a typical flank scale. Two other more elongate scales (ANU V3103, 3104) show a similar distinct groove surrounding the cosmine field. The inner ridge is more narrow, and in ANU V3104 has the appearance of an attached separate structure, rather than an integral part of the scale.

Comparisons: We do not know of any similar osteolepidid scales from the Devonian; such scales with a serrated posterior margin have not previously been recorded. These scales evidently belong to a new osteolepidid taxon, but until more material is available we leave them in open nomenclature.

Order Holoptychiida Andrews, 1967

Family Holoptychiidae Owen, 1860

\section{? holoptychiid indet.}

Fig. 9E

?1995 'scales of a sarcopterygian' (pars) - Turner: 683. 2000 'porolepiform crossopterygian' - Turner et al.: 502. Material: One scale (ANU V3107).

Locality and Age: Southern part of the Toomba Range, western Queensland, approximate latitude $23^{\circ} 23^{\prime} 47^{\prime \prime}$ S, longitude $138^{\circ} 08^{\prime} 10^{\prime \prime} \mathrm{E}$ (Abudda Lakes 1:100 000 sheet); horizon uncertain (?BCU, Fig. 2C); Emsian - Eifelian.

Description: Extracted from the residue of ANU V2969 was a single round scale $(4 \times 4 \mathrm{~mm})$ with ridged ornament of 'holoptychiid' type. It has a depressed anterior rim, and a raised free field with about nine subparallel slightly nodose ridges covering its anterior half (Fig. 9E). The ridges decrease in width posteriorly, reducing to a series of short ridges and posteriorly directed tubercles becoming smaller towards the posterior edge. The inner scale surface, which lacks any internal ridge or boss, is thickened and gently convex anteriorly, with a few pores, and forms a thinner porous posterior flange which would have overlapped the scale behind. 


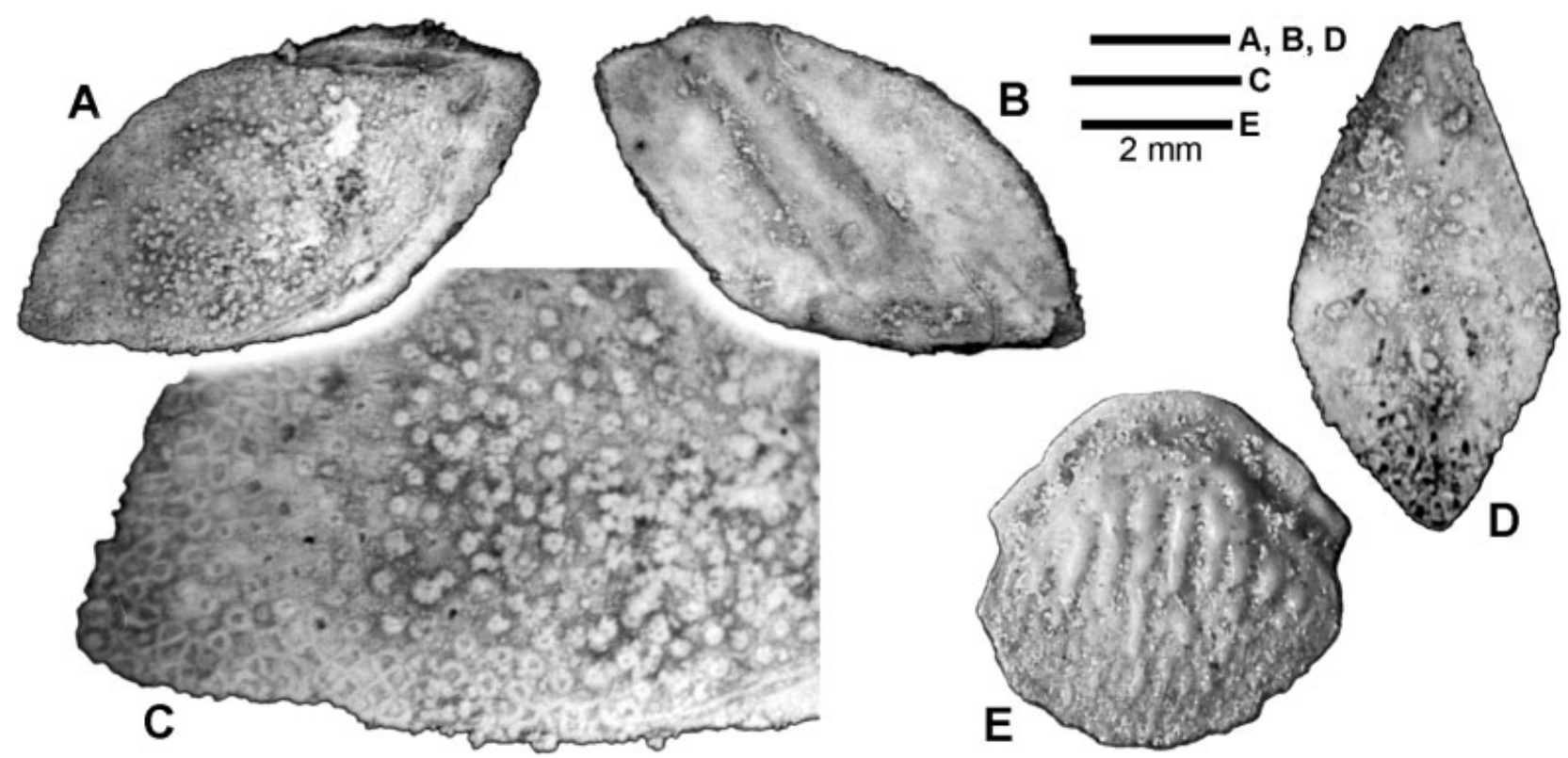

Fig. 9. A-D - Osteolepidid n. gen., n. sp. A-C - ANU V3101 in external (A) and internal (B) views, with detail of the posteroventral external surface (C); D - ANU V3102, external view; E - holoptychiid gen. et sp. indet., scale in external view (ANU V3107). Southern Toomba Range (locality 15, Fig. 1A), Queensland.

Infraclass Onychodontida Andrews, 1973 Family Onychodontidae Woodward, 1891

\section{Luckeus n. gen.}

Diagnosis: An onychodontid in which the lower jaw dentition comprises a main row of larger lingually curved anteroposteriorly compressed teeth alternating with sockets of subrectangular shape, a lateral row of smaller teeth alternating with tooth sockets in a less regular pattern, and an outer marginal laterally projecting ridge of crowded denticles, some enlarged as curved small teeth; inner dentary ridge reduced in thickness anterior to tooth row; anterior part of Meckel's cartilage perichondrally ossified, and with a deep fossa for the parasymphysial tooth whorl with minimal dermal attachment. Jaw symphysis with combined cartilaginous and dermal connection. Parasymphysial teeth with a barbed tip and striated at a density of $30-50 / \mathrm{mm}$.

Type species: Luckeus abudda n. sp.

Derivatio nominis: From the nick-name 'Lucke' of the late Dr. Hans Ludolph Jessen (Köln), to acknowledge his major contribution to the study of Palaeozoic osteichthyans, in particular onychodontids (Jessen 1966) and rhipidistians (Jessen 1968, 1980).

Remarks: The new taxon differs from previously named onychodontid genera in the number of tooth rows, cross section of teeth, shape of teeth in the outer row, and the form of the parasymphysial tooth whorl attachment to Meckel's cartilage.

\section{Luckeus abudda n. sp.}

Fig. 10A-E

1984 'onychodontid remains' - Young: 66.

1987 'crossopterygian ... remains' - Turner \& Young: 233. 1995 'onychodontid teeth' - Turner: 683.
2000 'onychodontids' - Turner et al.: 502.

2003 'smaller onychodontid' - Young \& Goujet: 75.

Diagnosis: See diagnosis of genus.

Holotype: ANU V2969 (left lower jaw).

Additional material: Various isolated teeth (ANU V3108-3112)

Locality and Age: Southern part of the Toomba Range, western Queensland, approximate latitude $23^{\circ} 23^{\prime} 47^{\prime \prime} \mathrm{S}$, longitude $138^{\circ} 08^{\prime} 10^{\prime \prime} \mathrm{E}$ (Abudda Lakes 1:100 000 sheet); horizon uncertain (?BCU, Fig. 2C); Emsian - Eifelian.

Derivatio nominis: From Abudda Lakes, located in the Simpson Desert about $15 \mathrm{~km}$ ESE of the fossil locality.

Description: ANU V2969 is a small onychodontid left lower jaw preserved in two pieces (Fig. 10B), which was prepared using acetic acid digestion in Berlin in 2001. The Cravens Peak limestone material is exceptionally fragile during preparation, and the specimen is not yet completely extracted. We provide this preliminary description to document the interesting morphology of this specimen. The residue from the acid digestion yielded a variety of osteichthyan scales as described above, as well as antiarch bones like those described by Young (1984), various acanthodian remains (Burrow \& Young 2005), and a perfectly preserved typical tooth of the chondrichthyan Mcmurdodus whitei Turner \& Young, 1987. This is still partly embedded in the limestone matrix (tth, Fig. 10B).

The lower jaw has a preserved length of about $60 \mathrm{~mm}$, but the posterior margin is not fully prepared. The outer dermal surface carries external ornament of indistinct elongate partly anasto- 
mosing ridges, and includes a well preserved dentary inflected upwards at the front, and a prominent ventral expansion formed by the inwardly inflected anterior infradentary (De, $\mathrm{Id}_{1}$, Fig. 10A). There is no anterodorsal notch in the dentary, of the type described in Psarolepis by Zhu \& Schultze (1997) and Yu (1998), but the ventral expansion of the dermal cover corresponds to the extended anterior infradentary of Strunius as illustrated by Jessen (1966: fig. 10),

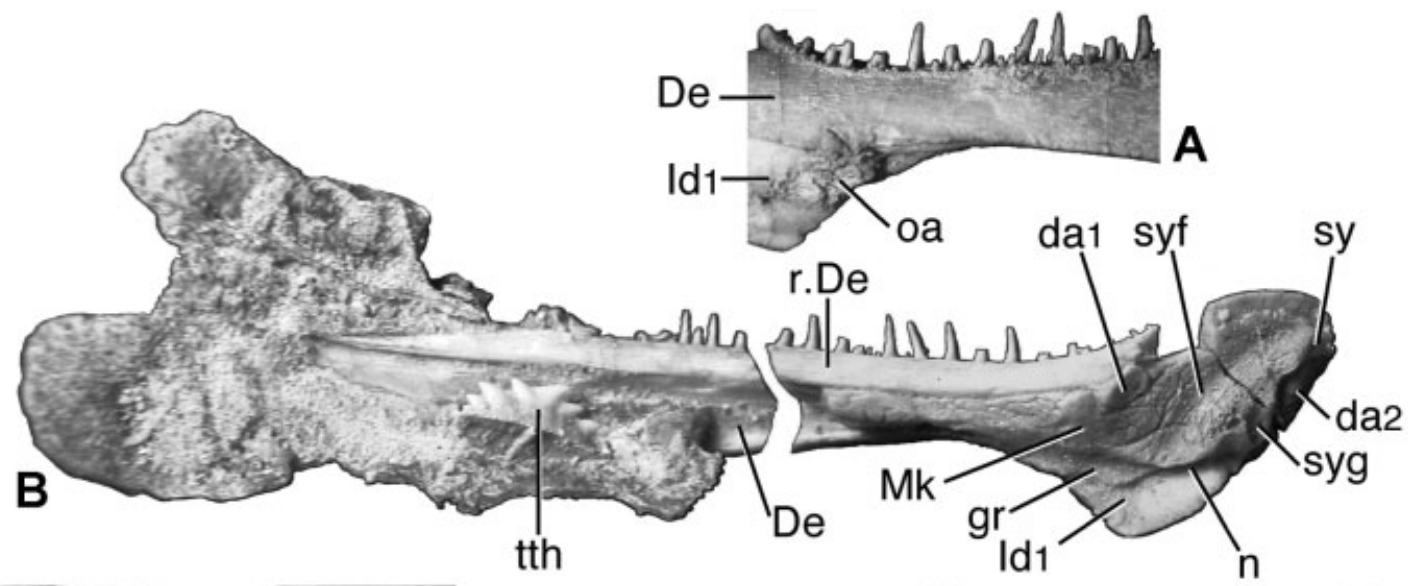

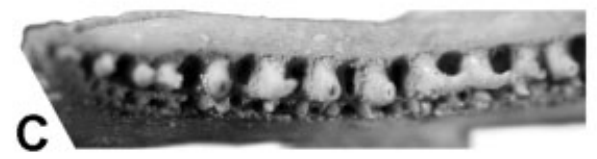
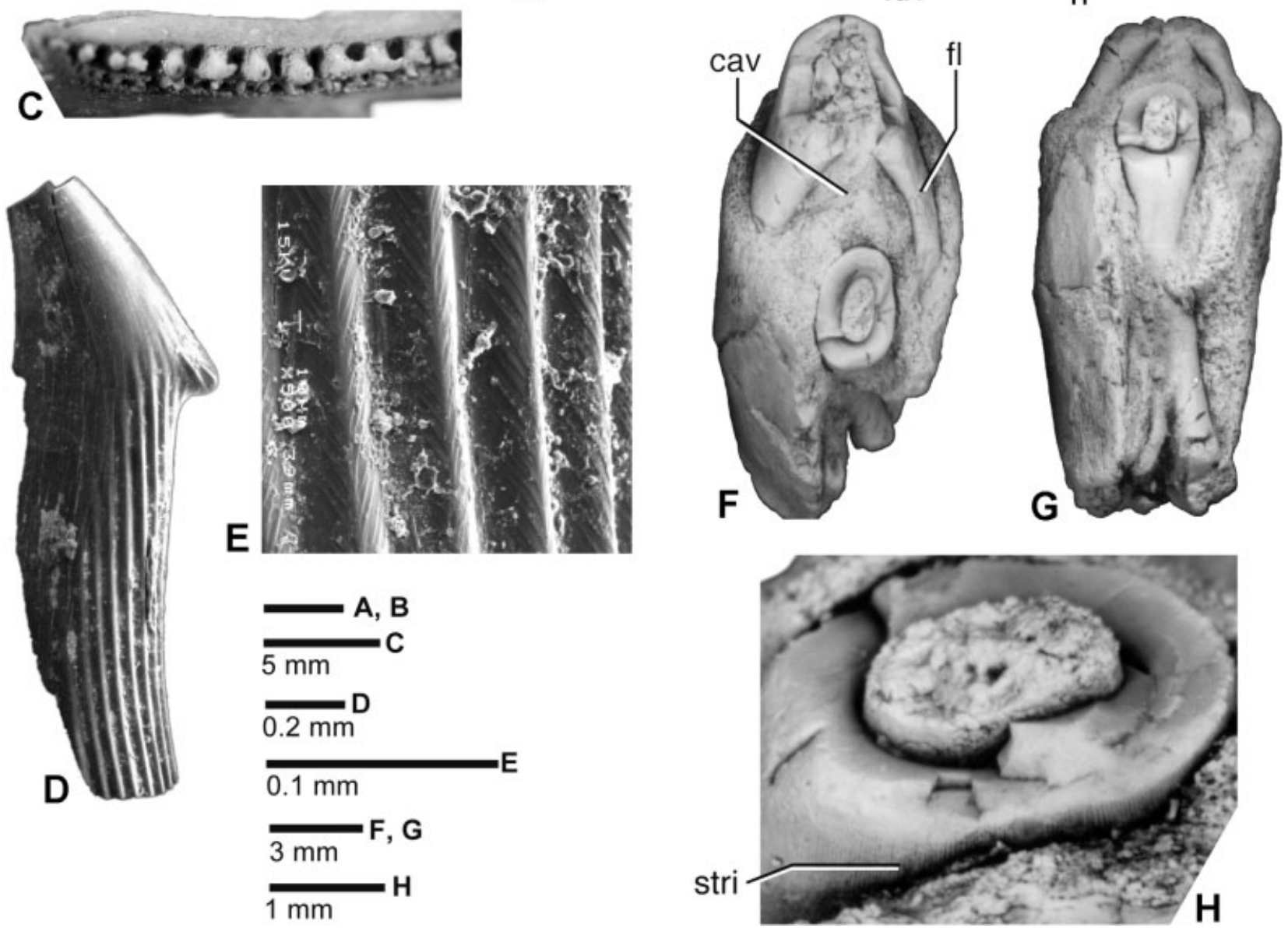

Fig. 10. Onychodontid remains from central Australia. A-E - Luckeus abudda n. gen., n. sp. from Southern Toomba Range, Georgina Basin, Queensland (locality 15, Fig. 1A); F-H - Specimen from Mt. Winter, Amadeus Basin, central Australia (locality 19, Fig. 1A); A-C - Left lower jaw (holotype, ANU V2969); part of external surface (A), the preserved internal surface (B), and an occlusal view of the anterior part of the dentition (C, anterior to left); $\mathbf{D}$ - Isolated fragment of parasymphysial tooth (ANU V3112), with detail of striated enamel (E); F-H - Incomplete parasymphysial tooth whorl (ANU V3039) in dorsal $(\mathbf{F})$ and posterior $(\mathbf{G})$ views, with detail of striated enamel $(\mathbf{H})$. cav - posterior cavity at base of onychodont tooth; $\mathbf{d a}_{1}$ - small boss of presumed dermal bone for tooth whorl attachment; da 2 - presumed dermal attachment as part of jaw symphysis; De - dentary; fl - posterior process on tooth base; gr - vascular groove; Id $\mathbf{1}$ - first infradentary; Mk - Meckel's cartilage (perichondrally ossified); $\mathbf{n}$ - notch; oa - contact for adjacent infradentary; r.De - inner ridge of dentary; stri - fine striation; sy - inner lamina of Meckel's cartilage enclosing parasymphysial tooth whorl; syf - attachment fossa for parasymphysial tooth whorl; syg - area for lower jaw symphysis on Meckel's cartilage; tth - chondrichthyan tooth (Mcmurdodus whitei). 
the 'anterior infradentary flange' illustrated by Chang \& Yu (1997: fig. 3), and the "ventro-mesial flange of the splenial' in Psarolepis ( $\mathrm{Zhu} \& \mathrm{Yu}$ 2004: fig. 1B). The suture between the dentary and anterior infradentary is visible externally, running forward along an angle in the dermal surface such that the external surface of the dentary faces laterally, and that of the anterior infradentary faces ventrolaterally. In lateral view the first infradentary is more triangular than restored for Strunius (Jessen 1966: fig. 10D), with a deeper less rounded ventral angle, and the sharp anterior angle slightly behind the anterior end of the dentary. The rounded anterior expansion of the dorsal edge of the dentary is more elongate than in Strunius, but less elongate than in an isolated onychodontid dentary from China (Zhu \& Janvier 1994), which has a more pointed anterior margin. The posterior margin of the anterior infradentary shows a roughened surface (oa, Fig. 10A) for interlocking with an adjacent bone (second infradentary), not identified in Strunius, nor in Grossius or Onychodus sigmoides, although a series of infradentaries is present in the Gogo Onychodus (Long 2001: fig. 1). Several deep pits entering the bone in this overlap presumably include a foramen for the passage of the mandibular sensory canal.

The inner surface of the dentary shows a thickened upper ridge (r.De, Fig. 10B), which carries the dentition. This comprises a main row of larger socketed teeth up to $2 \mathrm{~mm}$ long, most of which alternate with sockets where teeth have been lost. There are seven larger teeth on the posterior and 13 on the anterior preserved section. These decrease in size towards the front, with a small tooth cluster at the anterior end of the row. The teeth are antero-posteriorly compressed, with a marked lingual curvature at their tips. The tooth surface appears smooth, so if striations are present in the enamel they are very fine. Such striations on the lingual surface were said to be characteristic of the teeth of Strunius and Onychodus by Jessen (1966: 363). The sockets show the tooth bases to be about $1 \mathrm{~mm}$ in the lingual-labial dimension, and about $0.5 \mathrm{~mm}$ antero-posteriorly. Similar sockets, with a 'subrectangular' shape in a dentary ascribed to 'Onychodus sp.' by Turner et al. (2000: fig. 5.5), can be contrasted with the rounded tooth sockets of Onychodus sigmoides and Onychodus jaekeli (Jessen 1966: fig. 12C, pl. 20, fig. 1).

In occlusal view (Fig. 10C) the main tooth row is flanked by a lateral row of about 26 smaller teeth (approaching $1 \mathrm{~mm}$ in length) which again tend to alternate with tooth sockets, but in a less regular pattern. The outer margin of the dentition comprises a ridge of crowded denticles, some clearly enlarged as curved immature teeth (maximum length about $0.5 \mathrm{~mm}$ ). Jessen (1966: 375) distinguished Strunius from Onychodus lower jaws by the thickened elevated oral rim in the latter, which was contrasted with the flat rim in Strunius (Jessen 1966: figs 10, 12C, D). In ANU V2969 this outer rim also projects laterally from the main dermal bone surface (Fig. 10A). The lateral row of smaller socketed teeth was evidently not developed in Onychodus sigmoides (Jessen 1966: fig. 12C), nor in the Gogo Onychodus (K. S. W. Campbell, pers. comm.). However the latter has at least four coronoids fused inside the marginal dentition (Long 2001), whereas in primitive osteichthyans the coronoids were evidently loosely attached and readily lost ( $\mathrm{Zhu} \& \mathrm{Yu}$ 2004). There is no evidence of coronoids in Strunius, nor in Luckeus abudda n. sp., but outgroup comparison would suggest that they were either non-preserved, or secondarily lost.

ANU V2969 includes the anterior end of a perichondrally ossified Meckel's cartilage attached to the inner surface beneath the thickened dentary ridge (Mk, Fig. 10B). The ossified cartilage is hollow posteriorly, with an inner perichondral layer completely separate from the dermal bone to which it is attached, presumably the primitive condition for osteichthyans. Another early osteichthyan with a similar structure preserved is the 'mentomeckelian bone' on the lower jaw illustrated by Zhu \& Schultze (1997: fig. 4) belonging to Psarolepis Yu, 1998 from the Lower Devonian (Lochkovian) of China (see also Zhu \& Yu 2004: fig. 4). In Luckeus abudda n. sp. the anterior end of the cartilage is expanded both dorsally and ventrally, with an extensive concave area on its mesial surface covered with vascular grooves (syf) that must have been the attachment area for a parasymphysial tooth whorl. The large ventral expansion is completely different to the anterior end of Meckel's cartilage in Psarolepis or Achoania as described by Zhu \& Yu (2004: figs 3, 4), which carries a large oval anterior fenestra in this position. Assuming this area is completely preserved (i.e. that the 'anterior fenestra' is not an opening into the 'interperichondral space'; see Miles \& Young 1977: 145), then the ventral expansion of Meckel's cartilage to support the parasymphysial tooth plate in Luckeus abudda n. sp. would be a specialised feature. Posterodorsally, this 'para- 
symphysial lamina' of Meckel's cartilage partly surrounds a rounded projection $\left(\mathrm{da}_{1}\right)$ apparently continuous with the dentary ridge, which represents a small dermal attachment area for the parasymphysial tooth whorl. Anterodorsally the lamina has a clear edge about $1 \mathrm{~mm}$ inside the thin dorsal margin of the dentary, where it curves up in front of the dentary ridge. The smaller vascular grooves covering the perichondral attachment surface arise from a large groove running along the ventral ossified surface of the cartilage (gr), from which the contained vessel passed to the anterior in a deep notch (n) between the expanded anterior end of Meckel's cartilage and the inner dermal bone surface. Small branches from the main groove can be seen passing around the mesial surface of the cartilage near its posterior preserved end (Fig. 10B). In a similar position is the infradentary foramen' associated with the posterior end of the 'anterior Meckelian fenestra' in Psarolepis, and the ventral indentation 'for nerves and blood vessels' in the lower jaw of Achoania (Zhu \& Yu 2004: figs 3, 4).

The anterior edge of the tooth whorl attachment area forms a deep notch, with a mesial lamina (broken posteriorly) that would have enclosed the tooth whorl in a deep groove as reconstructed for Strunius rolandi (Gross) by Jessen (1966: fig. 10A, B). Several examples show the detail of this structure (Jessen 1966: pl.16, figs $6-9$, pl. 17, fig. 1), which may be a specialisation of early onychodontids, lost in later forms or modified by reduction of the ossified cartilage and more extensive dermal support (see below). At the anteroventral edge of Meckel's cartilage in ANU V2969 there is a separate deep depression for the jaw symphysis (syg, Fig. 10B), also in a similar position to that of Strunius. The depression is incomplete dorsally because of the broken mesial lamina, and may have been an elongate vertical groove as illustrated for Strunius rolandi by Jessen (1966: pl. 17, fig. 1). The symphysis has an anterior dermal component in the form of a rounded boss delineated by shallow grooves $\left(\mathrm{da}_{2}\right)$, with a flat attachment surface. This may correspond to the smaller anterior symphysial connection illustrated by Jessen (1966: pl. 16, fig. 8). This attachment has the same more opaque bone texture as the attachment developed posterodorsally $\left(\mathrm{da}_{1}\right)$, and both are interpreted as dermal components of the symphysial and tooth whorl attachments (alternatively they could be part of the edge of the cartilage separated off by vascular grooves).
As just described, the anterior end of the lower jaw of Luckeus abudda n. sp. is rather different from that of other onychodontids. The large 'symphysial area' delimited by a low ridge illustrated for Onychodus sigmoides (sya, Jessen 1966: fig. 12D) probably indicates the extent of attachment to the dentary of the expanded anterior end of Meckel's cartilage (unossified, or not preserved). Above this, the parasymphysial tooth whorl was placed on a thickened dentary ridge, and a similar arrangement, with Meckel's cartilage only in the symphysis, is seen also in porolepiforms, for example Glyptolepis and Holoptychius (Gross 1942: figs 2A-C, 6). In Onychodus from Gogo (Long 2001: fig. 3C, D) the tooth whorl apparently sits inside and against the thickened anterior end of the dentary ridge, as in holoptychiids (but its alignment with the braincase suggests a gap filled with cartilage; J. A. Long, pers. comm.). The essential difference from the holotype of Luckeus abudda n. sp. is that the inner dermal ridge of the dentary, which sits above the groove for Meckel's cartilage (unossified in Onychodus), expands anteriorly to provide a support for the tooth whorl, whereas in ANU V2969 the dentary ridge reduces to a narrow strip, with only a small dermal attachment process $\left(\mathrm{da}_{1}\right)$, and Meckel's cartilage is expanded to carry the major part of the tooth whorl attachment. In contrast, both the jaw symphysis and the attachment for the parasymphysial dental plate for Psarolepis were described as being on the inner surface of the dentary ( $\mathrm{Yu}$ 1998: figs 5, 6). Zhu \& Yu (2004: fig. 7) illustrate a sequence of lower jaw character transitions on a cladogram of major sarcopterygian groups, with a 'mesial horizontal ledge of the dentary' as a new character of onychodontids (their character 5). The lower jaw of Luckeus abudda n. sp. shows that the posterior part of this structure developed first, as may also be indicated by an indeterminate dentary from Yunnan, China, considered by Zhu \& Yu (2004: fig. 6A-F) to be a possible onychodontid. Still unclear is the primitive osteichthyan arrangement for dermal versus endochondral connections at the jaw symphysis and parasymphysial dental plate attachment, but the Psarolepis specimen illustrated earlier by Zhu \& Schultze (1997: fig. 4B, C) suggests that both attachments were carried on a perichondrally ossified 'mentomeckelian bone'.

The posterior preserved end of Meckel's cartilage is a broken edge, with a thick perichondral layer (slightly perforated ventrally in the main 
vascular groove), so it is uncertain whether Meckel's cartilage was unossified posteriorly, or whether it was lost during preparation of the posterior part of the jaw. The corresponding 'mentomeckelian bone' of Psarolepis apparently has a similar posterior termination (Zhu \& Schultze 1997: fig. 4).

Additional to this lower jaw are various isolated onychodont teeth from the southern Toomba Range locality. These are not uncommon in the limestone samples, and we assume they belong to the same taxon. The examples documented here, in unetched limestone samples (ANU V3108-3111), range in size up to $13 \mathrm{~mm}$ long. In the Gogo Onychodus the parasymphysial teeth may be 2-3 times the length of dentary teeth (Long 2001: fig. 1A), so these isolated teeth probably came from parasymphysial tooth whorls associated with somewhat larger lower jaws. ANU V3109 is missing the tip, but would have been about $13 \mathrm{~mm}$ long, with the proximal preserved part (about one third tooth length from the base) being $2 \mathrm{~mm}$ in diameter, oval in cross section, and showing 45-50 striations right around the exposed half of the enamel surface (density about $25 / \mathrm{mm}$ ). ANU V3111 is a broken tooth with $6 \mathrm{~mm}$ length preserved, and $1.5 \mathrm{~mm}$ across at the basal preserved part. Again the tooth is laterally compressed, with a striated enamel surface at a density of about $25 / \mathrm{mm}$. ANU V3108 was at least $12 \mathrm{~mm}$ long (mainly an eroded impression in limestone), but with $3 \mathrm{~mm}$ of the tip of the tooth preserved, showing that it had a barbed end, a feature first described by Gross (1965) in Onychodus jaekeli from Wildungen, and 'Hamodus' from the Middle Devonian of the Russian platform. Similar barbed teeth occur in an undescribed species from Lode, Latvia (Frasnian) assigned to Onychodus by Upeniece (1995). ANU V3110 is another tooth $13 \mathrm{~mm}$ long, probably also with a barbed end (covered by matrix). The barbed structure is well shown in the SEM of the tip of another parasymphysial tooth (V3112; Fig. 10D), a $1.6 \mathrm{~mm}$ long fragment presumably from a tooth at least 5-6 mm long. Higher magnification (Fig. 10E) shows the distinctive 'herringbone' or chevron pattern of ribs along the longitudinal ridges, just as illustrated by Smith (1989: fig. 4C) in Onychodus from Gogo, and said to be a specialised feature of onychodonts (Onychodus and Strunius). The striations are reduced with wear, but the large parasymphysial teeth of Onychodus from Gogo are mainly smooth (K. S. W. Campbell, pers. comm.). The 6-7 striations across the prox- imal preserved end of V3112 (Fig. 10D) suggests a density of $\sim 30 / \mathrm{mm}$.

\section{onychodontid gen. et sp. indet.}

Fig. $10 \mathrm{~F}-\mathrm{H}$

Material: ANU V3039 (incomplete tooth whorl).

Locality and Age: $30 \mathrm{~m}$ above the base of the 'OPK' section (see Fig. 2A), about $3.7 \mathrm{~km}$ northwest of the summit of Mount Winter, Amadeus Basin, central Australia (Fig. 1A, B; southwestern corner of the Mount Liebig 1:250000 sheet, see Scrimgeour et al. 2005); Emsian - Eifelian.

Description: ANU V3039 is a weathered incomplete onychodont tooth whorl showing the basal portion of two teeth enclosed in the bony lamina of the parasymphysial dental plate (Fig. 10F). Comparison with similar elements in the Gogo collection indicates that the preserved portion represents the anterior end of the whorl. The basal part of the larger anterior tooth shows paired posterior processes (fl) enclosing a large posterior cavity at the tooth base (cav), just as figured for Onychodus by Gross (1965: fig. 1e, d). The second tooth shows the basal $10 \mathrm{~mm}$ enclosed in the parasymphysial plate (Fig. 10G), with its crenellated base again typical of onychodonts (Gross 1965; Schultze 1969). The broken tooth sections in dorsal view are laterally compressed (anterior tooth $5 \times 4 \mathrm{~mm}$; posterior $4 \times 2.8 \mathrm{~mm}$ ). Higher magnification (Fig. 10H) shows the fine striations in the tooth enamel. These have a density of $\sim 30 / \mathrm{mm}$, similar to the parasymphysial teeth from the previous locality.

Comparisons: Previously named onychodontid genera are Onychodus Newberry, 1857, Strunius Jessen, 1966 and Grossius Schultze, 1973. Quebecius Schultze, 1973, first described as an onychodontid, was later re-assessed as a porolepiform (Schultze \& Arsenault 1987; Cloutier \& Schultze 1996). Onychodontids are mainly represented in the fossil record by many occurrences of isolated teeth in Devonian and Carboniferous strata (Schultze 1973). Records of more complete remains include jaw remains from the Pragian of China and Emsian of Australia (Zhu \& Janvier 1994; Ørvig 1969; Lindley 2002), and associated skull remains from the Eifelian of Morocco (Aquesbi 1988), said to resemble Grossius from the Eifelian of Spain. Exceptionally preserved acid-prepared material from the famous Upper Devonian (Frasnian) Gogo deposit, Western Australia, is by far the most complete onychodont material, and represents a new species 
of Onychodus (Long 2001; Andrews et al. in press).

Assuming all material from the Cravens Peak limestone locality belonged to the same taxon, it cannot be referred to the much smaller genus Strunius (total length of fish $100 \mathrm{~mm}$; Jessen 1966: 334), whilst the type and only known species of Grossius was much larger (Schultze 1973). The only named taxon with parasymphysial teeth with a barbed tip is Onychodus jaekeli from Wildungen (Frasnian), but in that form the parasymphysial whorl is mainly attached to the dentary, not Meckel's cartilage, and the tooth sockets on the dentary are round (Jessen 1966: pl. 20), both significant differences from the holotype of Luckeus abudda n. sp. described above. Both features are also seen in Onychodus sigmoides and the Gogo Onychodus (Jessen 1966: fig. 12C; Long 2001: fig. 3C, D), whereas Luckeus abudda $\mathrm{n}$. sp. differs from other onychodontids in that the dentary ridge is reduced anteriorly in front of the tooth row, and the parasymphysial tooth whorl is carried mainly or entirely on Meckel's cartilage. The 'subrectangular' tooth sockets resemble those on a dentary from the Eifelian of Queensland ascribed to 'Onychodus sp.' by Turner et al. (2000: fig. 5.5), but this lacks the lateral row of smaller socketed teeth, as do the lower jaws of other Onychodus and Strunius.

Regarding the characteristic striations of onychodont teeth, Lindley (2002: 122) described a contrasting anastomosing pattern in teeth named Onychodus yassensis from the Emsian of Burrinjuck, but other teeth from this locality also show the chevron pattern (Young, unpublished data). The striations of Lindley's material are much finer $(160-2000 / \mathrm{mm})$ than in the teeth described here (and would appear smooth under low magnifications). He suggested a trend of decreasing density of the striations through the Middle-Late Devonian of Australia, by comparison with Middle Devonian material from Queensland (Turner et al. 2000: pl. 2). However, striations on Emsian teeth from Broken River have a density of about 25/mm (De Pomeroy 1996: fig. 5B), and some Eifelian teeth are at least twice the density (Turner et al. 2000: pl. 2, fig. 2), so such a trend is not clearcut. Isolated teeth from China illustrated by Wang (1992: pl. 4, figs 1-5) show the typical resorbed base, and striated enamel on the distal end of one tooth (fig. 1). The age of these remains is Pragian-Emsian (Zhu et al. 2000). The small dentary described by Zhu \& Janvier (1994) as the oldest onychodontid is of Pragian age, and they suggested that lack of striations on its teeth was a generalised osteichthyan condition by which the jaw could be distinguished from all other onychodontids. Similar isolated teeth that are apparently 'smooth' (or with very fine striations) also occur commonly in Pragian deposits of central NSW (Burrow 1997, 2002). An indeterminate isolated dentary from China illustrated by $\mathrm{Zhu} \& \mathrm{Yu}$ (2004: fig. 6A-F) and interpreted to have possible onychodontid affinity is slightly older (late Lochkovian Xitun Formation; Zhu et al. 2000).

The single onychodontid specimen from Mount Winter (gen. et sp. indet.) evidently came from a somewhat larger form than that from the Cravens Peak locality. The striations on the parasymphysial teeth had a similar density (30-50/ $\mathrm{mm})$ to Luckeus abudda n. sp., but this applies also to other onychodontids, for example Grossius (40-50/mm; Schultze 1973: 203), and Onychodus jaekeli (30-40/mm; Gross 1965).

\section{Discussion}

\section{Biostratigraphy and correlation}

Revised faunal lists of the Devonian fish assemblages from the two studied localities are summarised in Table 2. The osteichthyan component comprises three major osteichthyan groups represented in both assemblages: dipnoans, osteolepidids, onychodonts. A fourth group (Porolepiformes) is represented at the Toomba Range locality by a single scale. The fact that within these groups different taxa are represented at the two localities indicates that they are either not the same age, or did not sample the same palaeoenvironments. Turner $(1995,1997)$ compared the thelodonts from the southern Toomba Range in the Georgina Basin with younger (Middle Devonian) turiniid scales from the Broken River sequence of Queensland, and the acanthodian assemblage also resembles Broken River forms (Burrow 2002; Burrow \& Young, 2005). Some resemblance was noted above between the holotype of Luckeus abudda n. sp. and onychodont jaw remains documented from the 'Fish Hill' locality at Broken River (Turner et al. 2000). This has been dated as middle Eifelian (costatus-australis conodont zones; for a review of Broken River Devonian fish ages see Young 2004). Thus there may be consistent evidence from thelodonts, acanthodians and now onychodontids for a similar Eifelian age for the Cravens Peak limestone in the southern Toomba Range. The apparently primitive position of the 
Table 2

Faunal lists of the Lower/Middle Devonian at Mt. Winter (locality 19, Fig. 1A) and at Southern Toomba Range (locality 15, Fig. 1A), central Australia.

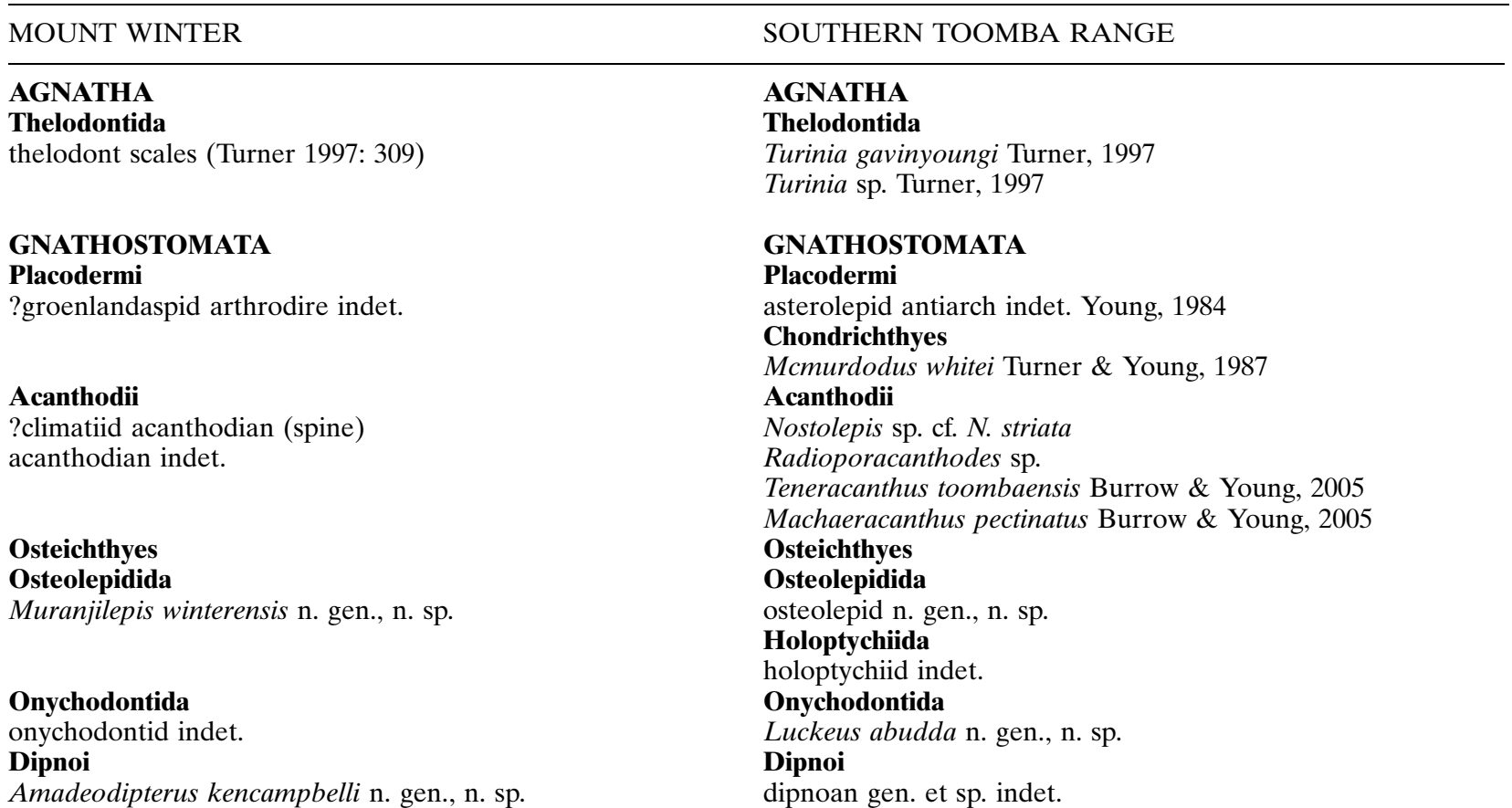

Amadeodipterus kencampbelli n. gen., n. sp.

tooth whorl in Luckeus abudda n. sp. might not be expected in such a young taxon (already lost in the Eifelian Onychodus sigmoides), but there are close similarities in this respect to Strunius rolandi from Kokenhusen (Latvia, Frasnian), so the onychodontid evidence of age remains equivocal.

\section{Biogeography}

Other groups from central Australia have provisionally indicated some faunal connections with South China in the Early-Middle Devonian, for example the arthrodire Toombalepis from the Cravens Peak Beds was grouped with Yujiangolepis from South China within the family Antarctaspidae by Young \& Goujet (2003). For osteichthyans, Long (2001) has suggested a close relationship between onychodontids and the Chinese Psarolepis, based on endocranial similarities indicated by the Gogo Onychodus. The apparently primitive position of the tooth whorl in the lower jaw of the new onychodontid Luckeus n. gen. may support this idea, consistent with the co-occurrence of onychodontid remains in preEmsian strata in China and Australia (see above). The new osteolepidid taxon Muranjilepis shows some characters also recorded in Chinese forms Thursius wudinengsis and Kenichthys campbelli. Relationships of Amadeodipterus n. gen. are uncertain, but it was evidently an endemic dipnoan, in contrast to the more typical 'dipterid' lungfish from younger strata (Harajica fauna; Fig. 2B) in central Australia (e.g. the undescribed skull of Young 1985: fig. 8J).

\section{Acknowledgements}

GCY thanks the Alexander von Humboldt Gesellschaft for six months support at the Museum für Naturkunde, Berlin, during two visits in 2000 and 2001, when preparation and study of this material was undertaken. For assistance with illustrations and photography we thank Mrs. E. Siebert, Mrs. C. Radke, and Dr. S. Schultka of the Museum für Naturkunde, Berlin. Dr. C. Burrow and Dr. J. Long are thanked for providing digital images of a lungfish scale and onychodontid jaw respectively. Professor K. S. W. Campbell and Dr. J. A. Long discussed and demonstrated the Gogo Onychodus material. R. Tracey, G. Menisky, and Dr. J. Draper provided field assistance and collaboration in the Georgina Basin, and local landowners (Johannsens of Baikal Station and Turners of Jinka Station) provided access to fossil localities. Dr. S. Turner participated in the discovery and collection of the Mount Winter material, and with Dr. C. Burrow has provided much information regarding the age of Devonian microvertebrate remains across Australia. Dr. P. J. Jones provided locality advice and information on field localities and Georgina Basin geology. R. W. Brown and H. M. Doyle (Geoscience Australia) and V. Elder (ANU) provided technical and curatorial assistance. This research is a contribution to IGCP Project 491, which provided financial assistance for a visit to Berlin in 2003 (GCY). We thank the reviewers, Drs. J. A. Clack and P. Janvier, for their improvement of the manuscript. 


\section{References}

Ahlberg, P. E. \& Johanson, Z. 1997. Second tristichopterid (Sarcopterygii, Osteolepiformes) from the Upper Devonian of Canowindra, New South Wales, Australia, and phylogeny of the Tristichopteridae. - Journal of Vertebrate Paleontology 17: 653-673.

Ahlberg, P. E., Johanson, Z. \& Daeschler, E. B. 2001. The Late Devonian lungfish Soederberghia (Sarcopterygii, Dipnoi) from Australia and North America, and its biogeographical implications. - Journal of Vertebrate Paleontology 21: 1-12.

Andrews, S. M. 1967. Class CROSSOPTERYGII. Pp. 641642. In Andrews, S. M., Gardiner, B. G., Miles, R. S. \& Patterson, C. Chapter 26. Pisces: 637-683. The Fossil Record. Geological Society of London, London.

- 1973. Interrelationships of Crossopterygians. In Greenwood, P. H., Miles, R. S. \& Patterson, C. (eds): Interrelationships of Fishes. - Zoological Journal of the Linnean Society 53, Supplement 1: 137-177.

Andrews, S. M., Long, J. A., Barwick, R. E., Ahlberg, P. E. \& Campbell, K. S. W. [in press]. Osteology and functional morphology of the sarcopterygian Onychodus jandemarrai n. sp. from Gogo, Western Australia. - Transactions of the Royal Society of Edinburgh 96.

Aquesbi, N. 1988. Etude d'un Onychodontiforme (Osteichthyes, Sarcopterygii) du Dévonien moyen (Eifelien) du Maroc. - Bulletin du Muséum national d'Histoire naturelle de Paris 10: 181-196.

Barwick, R. E., Campbell, K. S. W. \& Mark-Kurik, E. 1997. Tarachomylax: A new Early Devonian dipnoan from Severnaya Zemlya, and its place in the evolution of the Dipnoi. - Geobios 30 (1): 45-73.

Basden, A. M., \& Young, G. C. 2001. A primitive actinopterygian neurocranium from the Early Devonian of southeastern Australia. - Journal of Vertebrate Paleontology 21: $754-766$.

Basden, A. M., Young, G. C., Coates, M. I. \& Ritchie, A. 2000a. The most primitive osteichthyan braincase? - Nature 403: $185-188$.

Basden, A., Burrow, C. J., Hocking, M., Parkes, R. \& Young, G. C. 2000b. Siluro-Devonian microvertebrates from south-eastern Australia. In Blieck, A. \& Turner, S. (eds): 'IGCP 328, Final Report'. - Courier Forschungsinstitut Senckenberg 223: 201-222.

Boulenger, G. A. 1901. Les poissons du basin du Congo. LXXI + 532 pp., l'Etat Indépendant du Congo.

Burrow, C. 1994. Form and function in scales of Ligulalepis toombsi Schultze, a palaeoniscoid from the Early Devonian of Australia. - Records of the South Australian Museum 27 (2): 175-185.

- 1995a. A new palaeoniscoid from the Lower Devonian Trundle beds of Australia. - Geobios, Mémoire Spécial 19: $319-325$.

- 1995b. A new lophosteiform (Osteichthyes) from the Lower Devonian of Australia. - Geobios, Mémoire Spécial 19: $327-333$.

- 1997. Microvertebrate assemblages from the Lower Devonian (pesavis/sulcatus zones) of central New South Wales, Australia. - Modern Geology 21: 43-77.

- 2002. Lower Devonian acanthodian faunas and biostratigraphy of south-eastern Australia. - Memoirs of the Association of Australasian Palaeontologists 27: 75137.

Burrow, C. J. \& Young, G. C. 2005. The acanthodian fauna of the Cravens Peak Beds (Early to Middle Devonian), western Queensland. - Queensland Museum Memoirs 51: 325.

Campbell, K. S. W. \& Barwick, R. E., 1999. Dipnoan fishes from the Late Devonian Gogo Formation of Western Australia. - Records of the Western Australian Museum, Supplement 57: 107-138.
Campbell, K. S. W., Barwick, R. E \& Lindley, I. D. 2000. New data on the structure of the Early Devonian lungfish Dipnorhynchus. - Alcheringa 24: 277-298.

Chang, M.-M. \& Yu, X. 1997. Reexamination of the relationship of Middle Devonian osteolepids - fossil characters and their interpretation. - American Museum Novitates 3189: $1-20$.

Chang, M.-M. \& Zhu, M. 1993. A new Middle Devonian osteolepidid from Qujing, Yunnan. - Memoir of the Association of Australasian Palaeontologists 15: 183-198.

Cloutier, R. 1997. Morphologie et variations du toit crânien du dipneuste Scaumenacia curta (Whiteaves) (Sarcopterygii), du Dévonien supérieur du Québec. - Geodiversitas 19: $61-105$

Cloutier, R. \& Schultze, H.-P. 1996. Porolepiform fishes (Sarcopterygii). In Schultze, H.-P. \& Cloutier, R. (eds.): Devonian Fishes and Plants of Miguasha, Quebec, Canada: 248-270, Verlag Dr. Friedrich Pfeil, München.

Cope, E. D. 1887. Zittel's Manual of Palaeontology. - American Naturalist 21: 1014-1019.

- 1889. Synopsis of the families of Vertebrata. - American Naturalist 23: 849-877.

De Pomeroy, A. M. 1996. Biostratigraphy of Devonian microvertebrates from Broken River, North Queensland. Records of the Western Australian Museum, Perth 17: 417-437.

Draper, J. J. 1976. The Devonian rocks of the Toko Syncline, western Queensland. - Bureau of Mineral Resources, Australia, Record 1976/29: 16 pp.

Etheridge Jr., R. 1906. The cranial buckler of a dipnoan fish, probably Ganorhynchus, from the Devonian beds of the Murrumbidgee River, New South Wales. - Records of the Australian Museum, Sydney 6: 129-132.

Fan J.-H. 1992. A new species of Thursius from Wuding, Yunnan. - Vertebrata PalAsiatica 30: 195-209.

Gardiner, B. G. 1984. The relationships of the palaeoniscid fishes, a review based on new specimens of Mimia and Moythomasia from the Upper Devonian of Western Australia. - Bulletin of the British Museum (Natural History), Geology series 37 (4): 173-428.

Gilbert-Tomlinson, J. G. 1968. A new record of Bothriolepis in the Northern Territory of Australia. - Bureau of Mineral Resources, Australia, Bulletin 80: 191-224.

Gross, W. 1965. Onychodus jaekeli Gross (Crossopterygii, Oberdevon), Bau des Symphysenknochens und seiner Zähne. - Senckenbergiana lethaea 46a: 123-131.

Hills, E. S. 1929. The geology and palaeontography of the Cathedral Range and the Blue Hills, in north-western Gippsland. - Proceedings of the Royal Society of Victoria 41: 176-201.

- 1959. Record of Bothriolepis and Phyllolepis (Upper Devonian) from the Northern Territory of Australia. - Journal and Proceedings of the Royal Society of N.S.W. 92: $174-175$.

Huxley, T. H. 1880. On the application of the laws of evolution to the arrangement of the Vertebrata and more particularly the Mammalia. - Proceedings of the Zoological Society of London 1880: 649-662.

Jarvik, E. 1948. On the morphology and taxonomy of the Middle Devonian osteolepid fishes of Scotland. - Kungliga Svenska VetenskapsAkademiens Handlingar 25 (3): 1301.

- 1985. Devonian osteolepiform fishes from East Greenland. - Meddelelser om Grønland (Geoscience) 13: $1-52$.

Jessen, H. 1966. Die Crossopterygier des Oberen Plattenkalkes (Devon) der Bergisch-Gladbach - Paffrather Mulde (Rheinisches Schiefergebirge) unter Berücksichtigung von amerikanischem und europäischem OnychodusMaterial. - Arkiv för Zoologi, Stockholm 18 (2): 305-389.

- 1968. A Devonian osteolepidid fish from British Columbia. - Geological Survey of Canada, Bulletin 165: 65-70. 
- 1980. Lower Devonian Porolepiformes from the Canadian Arctic with special reference to Powichthys thorsteinssoni Jessen. - Palaeontographica A 167: 180-214.

Johanson, Z. \& Ahlberg, P. E. 1997. A new tristichopterid (Osteolepiformes: Sarcopterygii) from the Mandagery Sandstone (Late Devonian, Famennian) near Canowindra, NSW, Australia. - Transactions of the Royal Society of Edinburgh: Earth Sciences 88: 39-68.

- 1998. A complete primitive rhizodont from Australia. Nature 394: 569-573.

Jones, B. G. 1972. Upper Devonian to Lower Carboniferous stratigraphy of the Pertnjara Group, Amadeus Basin, central Australia. - Journal of the Geological Society of Australia 19: 229-249.

- 1991. Fluvial and lacustrine facies in the Middle to Late Devonian Pertnjara Group, Amadeus Basin, Northern Territory, and their relationship to tectonic events and climate. - Bureau of Mineral Resources, Australia, Bulletin 236: $333-348$.

Kemp, A. 1999. Anomalies in skull bones of the Australian lungfish, Neoceratodus forsteri, compared with aberrations in fossil dipnoan skulls. - Journal of Vertebrate Paleontology 19: 407-429.

Lindley, I. D. 2002. Acanthodian, onychodontid and osteolepidid fish from the middle-upper Taemas Limestone (Early Devonian), Lake Burrinjuck, New South Wales. Alcheringa 26: 103-126.

Long, J. A. 1985. The structure and relationships of a new osteolepiform fish from the Late Devonian of Victoria, Australia. - Alcheringa 9: 1-22.

- 1987a. A redescription of the lungfish Eoctenodus Hills 1929, with reassessment of other Australian records of the genus Dipterus Sedgwick \& Murchison 1828. - Records of the Western Australian Museum 13 (2): 297-314.

- 1987b. An unusual osteolepiform fish from the Late Devonian of Victoria, Australia. - Palaeontology 30: 839852.

- 1988. New palaeoniscoid fishes from the Late Devonian and Early Carboniferous of Victoria. - Memoirs of the Association of Australasian Palaeontologists 7: 1-64.

- 1992. Cranial anatomy of two new Late Devonian lungfishes (Pisces: Dipnoi) from Mount Howitt, Victoria. Records of the Australian museum, Sydney 44: 299_ 318.

- 1999. A new genus of fossil coelacanth (Osteichthyes: Coelacanthiformes) from the Middle Devonian of southeastern Australia. - Records of the Western Australian Museum, Supplement 57: 37-53.

- 2001. On the relationships of Psarolepis and the onychodontiform fishes. - Journal of Vertebrate Paleontology 21: $815-820$

Long, J. A., Barwick, R. E. \& Campbell, K. S. W. 1997. Osteology and functional morphology of the osteolepiform fish, Gogonasus andrewsae Long, 1985, from the Upper Devonian Gogo Formation, Western Australia. - Records of the Western Australian Museum, Supplement 53: 1-90.

Miles, R. S. 1977. Dipnoan (lungfish) skulls and the relationships of the group: a study based on new species from the Devonian of Australia. - Zoological Journal of the Linnean Society 61: $1-328$.

Miles, R. S. \& Young, G. C. 1977. Placoderm interrelationships reconsidered in the light of new ptyctodontids from Gogo, Western Australia. In Andrews, S. M., Miles, R. S. \& Walker, A. D. (eds), Problems in vertebrate evolution. Linnean Society Symposium Series 4: 123-198.

Müller, J. 1845. Über den Bau und die Grenzen der Ganoiden, and über das natürliche System der Fische. - Abhandlungen der königlichen Akademie der Wissenschaften zu Berlin 1844: 117-216.

Newberry, J. S. 1857. Fossil fishes from the Devonian of Ohio. - Proceedings National Insitute, Washington, D. C. (new series) 1: 119-126.
Ørvig, T. 1969. Vertebrates from the Wood Bay Group and the position of the Emsian-Eifelian boundary in the Devonian of Vestspitsbergen. - Lethaia 2: 273-328.

Owen, R. 1860. Palaeontology; or, a systematic summary of extinct animals and their geological remains. $\mathrm{XV}+420$ pp., Adam and Charles Black, Edinburgh.

Parrington, F. R. 1950. The skull of Dipterus. - Annals and Magazine of Natural History, series 12, 3: 534-547.

Pridmore, P. A. \& Barwick, R. E. 1993. Post-cranial morphologies of the Late Devonian dipnoans Griphognathus and Chirodipterus and locomotor implications. - Memoirs of the Association of Australasian Palaeontologists 15: 161182.

Romer, A. S. 1955. Herpetichthyes, Amphibioidei, Choanichthyes or Sarcopterygii? - Nature 176: 126-127.

Schultze, H.-P. 1968. Palaeoniscoidea-Schuppen aus dem Unterdevon Australiens und Kanadas und aus dem Mitteldevon Spitzbergens. - Bulletin of the British Museum (Natural History), Geology 16 (7): 343-368.

- 1969. Die Faltenzähne der rhipidistiiden Crossopterygier, der Tetrapoden und der Actinopterygier-Gattung Lepisosteus; nebst einer Beschreibung der Zahnstruktur von Onychodus (struniiformer Crossopterygier). - Palaeontographica Italica 65 (n. ser. 35): 63-137.

- 1973. Crossopterygier mit heterozerker Schwanzflosse aus dem Oberdevon Kanadas, nebst einer Beschreibung von Onychodontida-Resten aus dem Mitteldevon Spaniens und aus dem Karbon der USA. - Palaeontographica, Abteilung A 143: 188-208.

- 1992a. Dipnoi. In Westphal, F. (ed.) Fossilium Catalogus, Pars 131: 1-46, Kugler Publications, Amsterdam, New York.

- 1992b. A new long-headed dipnoan (Osteichthyes, Pisces) from the Middle Devonian of Iowa, USA. - Journal of Vertebrate Paleontology 12: 42-58.

- 2001. Melanognathus, a primitive dipnoan from the Lower Devonian of the Canadian Arctic and the interrelationships of Devonian dipnoans. - Journal of Vertebrate Paleontology 21: 781-794.

Schultze, H.-P. \& Arsenault, M. 1987. Quebecius quebecensis (Whiteaves), a porolepiform crossopterygian (Pisces) from the Late Devonian of Quebec, Canada. - Canadian Journal of Earth Science 24: 2351-2361.

Schultze, H.-P. \& Bolt, J. 1996. The lungfish Tranodis and the tetrapod fauna from the Upper Mississippian of North America. - Special Papers in Palaeontology 52: 31-54.

Scrimgeour, I. R., Close, D. F. \& Edgoose, C. J. 2005. Mount Liebig, Northern Territory (Second Edition). 1:250000 geological map series explanatory notes, SF 52-16. Northern Territory Geological Survey, Darwin.

Smith, M. M. 1989. Distribution and variation in enamel structure in the oral teeth of sarcopterygians: Its significance for the evolution of a protoprismatic enamel. Historical Biology 3: 97-126.

Thomson, K. S. 1973. Observations on a new rhipidistian fish from the Upper Devonian of Australia. - Palaeontographica, Abteilung A 143: 209-220.

Turner, S. 1991. Palaeozoic Vertebrate Microfossils in Australasia. In Vickers-Rich, P., Monaghan, J. M., Baird, R. F. \& Rich, T. H. (eds), Vertebrate Palaeontology of Australasia: 429-464, Pioneer Design Studio Pty Ltd, Lilydale, Victoria.

- 1995. Devonian thelodont scales (Agnatha, Thelodonti) from Queensland. - Memoirs of the Queensland Museum 38: $677-685$.

- 1997. Sequence of Devonian thelodont scale assemblages in East Gondwana. - Geological Society of America Special Publication 321: 295-315.

Turner, S., Basden, A. \& Burrow, C. J. 2000: Devonian vertebrates of Queensland. In Blieck, A. \& Turner, S. (eds): 'IGCP 328, Final Report'. - Courier Forschungsinstitut Senckenberg 223: 487-521. 
Turner, S., Jones, P. J. \& Draper, J. J. 1981: Early Devonian thelodonts (Agnatha) from the Toko Syncline, western Queensland, and a review of other Australian discoveries. - BMR Journal of Australian Geology \& Geophysics 6: $51-69$.

Turner, S. \& Young, G. C. 1987: Shark teeth from the EarlyMiddle Devonian Cravens Peak Beds, Georgina Basin, Queensland. - Alcheringa 11: 233-244.

Upeniece, I. 1995. A new species of Strunius (Sarcopterygii, Onychodontida) from Latvia, Lode Quarry (Upper Devonian). - Geobios, Memoire Special 19: 281-284.

Wang N.-Z. 1992. Microremains of agnathans and fishes from Lower Devonian of central Guangzi with correlation of Lower Devonian between central Guangxi and central Yunnan, South China. - Acta Paleontologica Sinica 31: 280-303.

Wells, A. T., Forman, D. J. Ranford, L. C. \& Cook, P. J. 1970. Geology of the Amadeus Basin, central Australia. - Bureau of Mineral Resources, Australia, Bulletin 100: $222 \mathrm{pp}$.

Westoll, T. S., 1949. On the evolution of the Dipnoi. pp. 121184. In Jepsen, G. L., Mayr, E. \& Simpson, G. G. (eds): Genetics, paleontology and evolution. Princeton University Press, Princeton, New Jersey.

White, E. I., 1965. The head of Dipterus valenciennesi Sedgwick \& Murchison. - Bulletin of the British Museum (Natural History), Geology 11 (1): 1-45.

Woodward, A. S. 1891. Catalogue of the Fossil Fishes in the British Museum (Natural History). Part ii. containing the Elasmobranchii (Acanthodii), Holocephali, Ichthyodorulites, Ostracodermi. Dipnoi, and teleostomi (Crossopterygii and chondrostean Actinopterygii). xliv +567 pp., Trustees of the British Museum, London.

Young, G. C. 1984. An asterolepidoid antiarch (placoderm fish) from the Early Devonian of the Georgina Basin, central Australia. - Alcheringa 8: 65-80.

- 1985. New discoveries of Devonian vertebrates from the Amadeus Basin, central Australia. - BMR Journal of Australian Geology \& Geophysics 9: 239-254.

- 1988. New occurrences of phyllolepid placoderms from the Devonian of central Australia. - BMR Journal of Australian Geology \& Geophysics 10: 363-376.

- 1991. The first armoured agnathan vertebrates from the Devonian of Australia. In Chang M.-M., Liu Y.-H., \& Zhang G.-R. (eds.): Early Vertebrates and Related Problems of Evolutionary Biology: 67-85, Science Press, Beijing, China.

- 1993. Middle Palaeozoic macrovertebrate biostratigraphy of eastern Gondwana. Chapter 9. In Long, J. A. (ed.): Pa- laeozoic Vertebrate Biostratigraphy and Biogeography: 208-251, Belhaven Press, London.

- 1995. Timescales 4. Devonian. Biostratigraphic charts and explanatory notes. Second Series. - Australian Geological Survey Organization, Record 1995/33: 47 pp., 1 chart.

- 1996. Devonian (chart 4). In Young, G. C. \& Laurie, J. R. (eds): An Australian Phanerozoic Timescale: 96-109, Oxford University Press, Melbourne.

- 2004. A Devonian brachythoracid arthrodire skull (placoderm fish) from the Broken River area, Queensland. Proceedings of the Linnean Society of New South Wales 125: $43-56$.

- 2005. An articulated phyllolepid fish (Placodermi) from the Devonian of central Australia: implications for nonmarine connections with the Old Red Sandstone continent. - Geological Magazine 142: 173-186.

Young, G. C., \& Gorter, J. D. 1981. A new fish fauna of Middle Devonian age from the Taemas/Wee Jasper region of New South Wales. - Bureau of Mineral Resources, Bulletin 209: 83-147.

Young, G. C. \& Goujet, D. 2003. Devonian fish remains from the Dulcie Sandstone and Cravens Peak Beds, Georgina Basin, central Australia. - Records of the Western Australian Museum, Supplement 65: 1-85.

Young, G. C., \& Turner, S. 2000. Devonian microvertebrates and marine-nonmarine correlation in East Gondwana: Overview. - Courier Forschungsinstitut Senckenberg 223: 453-470.

Yu, X. 1998. A new porolepiform-like fish, Psarolepis romeri, gen. et sp. nov. (Sarcopterygii, Osteichthyes) from the Lower Devonian of Yunnan, China. - Journal of Vertebrate Paleontology 18: 261-274.

Zhu, M. \& Janvier, P. 1994. Un onychodontide (Vertebrata, Sarcopterygii) du Dévonien Inférieur de Chine. - Comptes Rendus de l'Academie des Sciences, Paris 319: 951956.

Zhu, M. \& Schultze, H.-P. 1997. The oldest sarcopterygian fish. - Lethaia 30: 293-304.

Zhu, M., Wang N.-Z. \& Wang J.-Q. 2000. Devonian macroand microvertebrate assemblages of China. - Courier Forschungsinstitut Senckenberg 223: 361-372.

Zhu, M. \& Yu, X. 2004. Lower jaw character transitions among major sarcopterygian groups - a survey based on new materials from Yunnan, China. In Arratia, G., Wilson, M. V. H. \& Cloutier, R. (eds), Recent advances in the origin and early radiation of vertebrates: 271-286. Verlag Dr. Friedrich Pfeil, München. 